\section{Jelena Zagora}

jelenzagor@gmail.com

Pregledni rad/Scientific review Primljen/Received: 17. 5. 2017.

UDK $75.023(450) " 14 / 17 "$

DOI http://dx.doi.org/10.17018/portal.2017.8

\section{Povijesni razvoj obojenih podloga u talijanskom slikarstvu od 15. do sredine 18. stoljeća - dosadašnje spoznaje i otvorena pitanja}

SAŽETAK: Uz povijesni pregled razvoja obojenih podloga $u$ Italiji od 15. do sredine 18. stoljeća, u radu se iznose razmatranja o nazivlju i tipologiji slikarskih preparacija. Članak objedinjuje reference o najranijim poznatim obojenim podlogama u talijanskom slikarstvu na drvu i na platnu, utvrđenim na djelima slikara sa sjevera zemlje iz 15. i ranog 16. stoljeća - od pojave pigmentiranog gessa i imprimatura do uvođenja obojenih preparacija u uljenom slikarstvu na platnu koje se koriste i razvijaju u dva stoljeća nakon toga. Autorica istražuje porijeklo crvenih preparacija iz 18. stoljeća i obrađuje sjevernoeuropske dvostruke preparacije, pronađene i na slikama talijanskih autora iz 17. i 18. stoljeća u Italiji i Dalmaciji. U Šibeniku je na oltarnoj pali venecijanskog slikara Angela Mancinija iz 1609. godine utvrđen podslik s funkcijom preparacije, odnosno obojene podloge. Prema dosadašnjem autoričinu istraživanju, sličan primjer nije zabilježen u uljenom slikarstvu na platnu.

KLJUČNE RIJĚI: pigmentirani gesso, imprimature, obojene preparacije, dvostruke preparacije, podslik, slikarstvo na drvu, uljeno slikarstvo na platnu
$\mathrm{S}$ jeverna Italija izvorište je širenja slikarstva na obojenim podlogama. Budući da je slikarska baština Dalmacije nastajala djelovanjem talijanskih umjetnika, odnosno domaćih umjetnika koji su bili pod talijanskim, poglavito venecijanskim estetskim i tehnološkim utjecajima, istraživanje preparacija dalmatinskih slika može biti zanimljiv doprinos poznavanju talijanskh preparacija i povijesti slikanja na obojenim podlogama. Cilj ove pretežito bibliografske studije jest obradom dosadašnjih spoznaja o temi otvoriti pitanja i naznačiti smjernice za nova istraživanja te, za početak, kontekstualizirati tipologiju nekoliko neobičnih primjera venecijanske provenijencije pronađenih $u$ Dalmaciji.
Osim zahtjevnog zadatka objedinjavanja podataka iz sve brojnijih publikacija o toj temi, osobit je izazov bio nedostatak jasno definiranog i općeprihvaćenog stručnog nazivlja kod nas, ali i u inozemstvu. Predložena terminologija odabrana je i definirana $u$ pokušaju usklađivanja uvriježene tradicije i suvremenih internacionalnih tendencija, kao podloga za daljnje rasprave i doprinos pojašnjavanju, preciziranju i ujednačavanju nazivlja.

\section{Obrazloženje nazivlja}

Prema opisu Siga Summereckera, uloga slikarske osnove ili preparacije kao sloja izvedenog na površini odabranog nosioca jest primiti i što čvršće vezati slikani sloj, povezati 
ga s nosiocem, kompenzirati divergentna gibanja nosioca i slikanog sloja te regulirati upijanje veziva boje, zaštititi nosioca od njegova štetnog djelovanja i dati opći ton slikanom djelu. ${ }^{1}$ Iako u domaćoj literaturi nazivlje slikarskih podloga nije ujednačeno, moglo bi se reći da su osnova i preparacija kod nas postali sinonimi koji se koriste $u$ dva raspona značenja: u užem smislu označavaju jedan segment stratigrafije slikarske podloge koji se nalazi između impregnacije nosioca i sloja nepigmentirane izolacije ili imprimature, dok prema široj definiciji obuhvaćaju sve slojeve pripreme za slikanje nanesene između nosioca i slojeva boje. ${ }^{2}$ Slična je situacija i u literaturi na engleskom jeziku - iako se o tome više raspravlja, nema jedinstvenog stava. Izrazi ground i preparation često se upotrebljavaju sinonimno, $u$ širem značenju. Ponekad se upotrebljava i naziv priming, premda ga neki autori nastoje ograničiti na uljene imprimature i obojene preparacije $u$ uljenom vezivu. ${ }^{3}$ Talijanski autori izraz preparazione koriste $u$ širem smislu, ali i za označavanje gipsano-tutkalne osnove (povijesno ingessatura), dok obojene, $u$ pravilu uljene izolacije osnove, kao i obojene (uljene) preparacije za platno, tradicionalno nazivaju imprimiture ili mestiche. ${ }^{4} \mathrm{U}$ doktorskoj disertaciji na temu povijesnih receptura slikarskih preparacija, Maartje Stols-Witlox pokušava razjasniti i redefinirati nazivlje preparacija u engleskom jeziku. Uz napomenu da brojni povijesni i suvremeni istraživači izraz ground koriste $u$ širem smislu, autorica smatra da su moderni nazivi preparation ili preparatory system ispravniji za označavanje svih slojeva pripreme nosioca za slikanje, uključujući i one manje uočljive, kao što su impregnacija nosioca i nepigmentirani izolacijski slojevi. Sugerira da se naziv ground ograniči na slojeve punila i pigmenata $u$ vezivu (izuzev pigmentirane izolacije). Preparaciju, sastavljenu od impregnacije, osnove i izolacije (impregnation, ground, isolation), definira kao slojeve između nosioca i slojeva boje, pod uvjetom da su jednoliko naneseni na cijelu površinu na kojoj će se slikati. Time se preparacija razlikuje od podslika - lokalnih nanosa boje koji se smatraju dijelom faze slikanja. ${ }^{5} \mathrm{U}$ skladu s tendencijama suvremene internacionalne terminologije, $u$ ovome radu zbog jasnijeg opisa složenih sustava, izraz preparacija upotrebljavam za označavanje cjelokupne stratigrafije svih tipova pripreme nosioca za slikanje s impregnacijom, osnovom i izolacijom. Terminom osnova označavam sloj, odnosno slojeve koji određuju teksturu podloge za slikanje, a kod nekih tipova i njezinu boju. Osnova preparacije stratigrafski je smještena između impregnacije i izolacije (ako su prisutne). Načelno se sastoji od veziva, punila i pigmenata, no može sadržavati i druge dodatke, primjerice sikative. Uloga čestica određenog materijala definira punilo, odnosno pigment, premda materijal može imati i dvojaku ulogu. ${ }^{6}$ Izraz gesso upotrebljavam kao naziv za tutkalnogipsanu osnovu. Osim impregnacije nosioca, preparacija od gessa može imati i nepigmentiranu izolaciju ili pak im- primaturu. Potonje se u članku uvijek posebno napominje, kako je uobičajeno i u stranoj literaturi. Zbog povijesnih razloga, naziv gesso zadržan je i u opisu prijelaznog tipa obojenih preparacija koje su se razvile iz imprimatura, premda u takvim slučajevima katkad gubi ulogu osnove. ${ }^{7}$ Tutkalno-gipsane preparacije s dodatkom male količine pigmenata, $u$ radu se označavaju izrazom pigmentirani gesso. ${ }^{8}$ Za primjere $u$ kojima je utvrđen gips kao punilo, no nije poznato i vezivo, koristim se općenitijom sintagmom gipsana preparacija.

Imprimatura se može definirati kao pigmentirana izolacija. Premda etimologija nije potpuno razjašnjena (vjerojatno od lat. in primitus: isprva, početi sa), povijesno je termin imprimatura označavao mješavinu pigmenata sikativnih svojstava u ulju koja je služila kako bi se preparacija od gessa (izvorno razvijena za temperno slikarstvo) prilagodila uljanom mediju. Suvremeni istraživači slažu se da je funkcija imprimature smanjenje apsorpcije i obojenje preparacije, stoga se definira kao providni ili pokrivni sloj koji prekriva cijelu površinu slike. ${ }^{9}$ Većina autora drži da je povijesno najprikladnije ograničiti značenje imprimature na pigmentirani sloj izolacije $u$ uljenom vezivu, nanesen na svijetlu osnovu s vodenim vezivom (gesso ili tutkalno-krednu osnovu). ${ }^{10}$

Preparacije s jednoslojnom ili višeslojnom blago ili snažno obojenom osnovom svrstala sam u skupinu obojenih preparacija, bez obzira na sastav veziva i eventualnu nepigmentiranu izolaciju. ${ }^{11}$ Sintagmom obojena podloga označavam obojeni sloj na kojem se slika, odnosno završni sloj preparacije koji određuje boju slikarske podloge. ${ }^{12}$

\section{Počeci slikanja na obojenim podlogama - 15. i 16. stoljeće u Italiji}

Uvođenje obojenih podloga $u$ povijesnom europskom slikarstvu povezuje se s promjenom stila i slikarske tehnike: jednoliko, meko i sjajno svjetlo renesansnih slika ustupa mjesto dramatičnijoj scenografiji s naglaskom na chiaroscuro efekt, što je znatno lakše postići na tamnoj podlozi. ${ }^{13}$ Iako se tehnologija izrade slika starih majstora još uvijek (i sve više) intenzivno istražuje, može se reći da je razvoj obojenih podloga određen i dvjema tehnološkim promjenama: postupnim prelaskom s tempernog na uljeno slikarstvo, a zatim uvođenjem platnenog nosioca. Platno tek u poodmaklom 16. stoljeću počinje prevladavati kao nosilac uljenih slika, poglavito $u$ Veneciji i povezanim središtima. ${ }^{14}$ Preparacije od gessa, odnosno krede vezane tutkalom pronađene na nekim od najranijih sačuvanih primjera uljenih slika na platnu, nastavak su tradicije prepariranja slika na drvu. ${ }^{15}$ Iz nepigmentiranih izolacijskih slojeva, uvedenih još u tempernom slikarstvu zbog reduciranja upojnosti preparacije, razvijaju se imprimature. ${ }^{16}$ Prema suvremenim izvorima, potkraj 15. stoljeća postaju uobičajene na talijanskim slikama na drvu. ${ }^{17}$ Obojene preparacije istovremeno se 
uvode $\mathrm{u}$ različitim tehnikama slikarstva na platnenom nosiocu u Italiji i Europi. ${ }^{18}$

Najranije analitički utvrđene obojene podloge $u$ uljenom slikarstvu potječu sa sjevera Italije, iz doline rijeke Po i Venecije, gdje se pojavljuju još sredinom 15. stoljeća. Dovodeći u pitanje općeprihvaćenu tezu o imprimaturama kao prvim obojenim podlogama $u$ talijanskom slikarstvu, Diego Cauzzi i Claudio Seccaroni objavljuju otkriće preparacija od gessa s dodatkom crvenih pigmenata na djelima venecijanskih slikara. ${ }^{19} \mathrm{Na}$ drvu prepariranom gessom s crvenim okerom, Gentile Bellini izradio je sliku Sv. Lorenzo Giustiniani oko 1465. godine (Seminario patriarcale, Venecija), dok je Carlo Crivelli u sljedeća dva desetljeća slikao na gessu obojenom cinoberom. Za sada, nisu mi poznati drugi primjeri pigmentiranog gessa na slikama. ${ }^{20}$ Najranije zabilježene imprimature 15. stoljeća nisu jednoliko nanesene pigmentirane izolacije svijetlog ili neutralnog obojenja (uobičajene u sljedećem stoljeću), nego su intenzivne boje ili imaju obilježja podslika. Još oko 1490. godine Giovanni Ambrogio de Predis u Milanu slika na crvenim imprimaturama od cinobera $i$ minija. Takve intenzivno obojene imprimature talijanska autorica Antonietta Gallone opisuje izrazom fondo cromatico, kao i one varirajuće boje. ${ }^{21}$ Iako nejednoliki nanosi u nekoliko boja više nalikuju na podslik i prema definiciji se ne ubrajaju u imprimature, vjerojatno često imaju i ulogu pigmentirane izolacije te se mogu promatrati kao slojevi s dvojakom funkcijom. Zbog toga, kao i zbog činjenice da su naneseni na gesso, odnosno da su tipološki i povijesno srodni imprimaturama, označavam ih opisnom sintagmom imprimatura varirajuće boje. Jedan od najranijih poznatih primjera je Botticellijevo Proljeće (oko 1482., Galerija Uffizi, Firenca); slikar je varirao boju imprimature od crne ispod lišća do bijele ispod inkarnata. ${ }^{22}$ Na prijelazu 15. u 16. stoljeće Bramantino koristi takve imprimature narančastih, ružičastih i crvenkastih nijansi. $^{23}$ Istovremeno su na djelima sjevernotalijanskih slikara Vincenza Foppe, Palme starijeg, Giorgionea i Dossa Dossija dokumentirane lokalne imprimature pretežito tamnih neutralnih boja. ${ }^{24}$

Uz i dalje uobičajene preparacije od gessa, katkad s (prljavo)bijelom imprimaturom, u 16. su stoljeću u Italiji učestale imprimature svijetlog do srednjeg tona, podjednako na slikama na drvu i na platnu. Variraju sastavom i bojom, ponekad i unutar opusa pojedinih slikara: od prigušene ružičaste, svijetlonarančaste i bež do blijedosive, a najčešće su tople smećkasto-sive boje. Najzastupljenije su sjeverno od Apenina i u Veneciji, gdje primjeri obuhvaćaju i djela Lorenza Lotta, Palme starijeg, Tiziana i Veronesea. ${ }^{25}$ Imprimature intenzivnih i tamnijih boja (narančaste, oker, smeđe i gotovo crne) pojavljuju se na drvu i na platnu još u prvim desetljećima 16. stoljeća. Najbrojnije su na djelima sjevernotalijanskih slikara, među kojima su Vincenzo Civerchio, Dosso Dossi, Romanino, Bernardino da Asola te Parmigianino, koji prvi uspješno iskorištava prednosti tamne površine za izravnije i brže slikanje. ${ }^{26}$ U Veneciji su pronađeni neobični primjeri crvenih imprimatura od pigmenata na bazi organskih bojila (crveni lak). ${ }^{27}$

Tehnologija prepariranja platna $u \mathbf{1 6}$. se stoljeću intenzivno istražuje. Tijekom većeg dijela stoljeća, nanošenje gessa i dalje je uobičajeni postupak pripreme platna za slikanje u Italiji, čak i kad je iznad njega nanesena imprimatura ili je njime tek popunjena tekstura platna prije postavljanja obojene preparacije. ${ }^{28}$ Preparacije s tankim gessom bile su naročito popularne u Veneciji, gdje su iznimno zabilježene i preparacije od olovne bijele, odnosno kalcijeva karbonata, ili s dodatkom kalcita. ${ }^{29} \mathrm{U}$ dokumentima, ali i prema dosadašnjim istraživanjima, preparacije intenzivnijeg obojenja također se povezuju s talijanskim tehnikama slikanja na platnu. ${ }^{30}$ Uljene preparacije izrazitog obojenja, sastavljene pretežito od zemljanih pigmenata, razvile su se u dolini rijeke Po. Correggiova slika na platnu Krist odlazi od svoje Majke, vjerojatno nastala još prije 1514. godine (Nacionalna galerija, London), najraniji je takav primjer - tamne je žućkastosmeđe boje (žuta i zelena zemlja s olovnom bijelom), a na platno nije prethodno nanesen gesso. ${ }^{31}$ Smatra se da je upravo Correggio odigrao važnu ulogu u prelasku na slikarstvo na platnenom nosiocu; $u$ tom je kontekstu zanimljiva teza o utjecaju najranijih slika na tutkaljenom platnu na razvoj obojenih preparacija. U tehnici tutkalne tempere, oslik je najčešće izveden izravno na impregniranom platnu koje čini podlogu sivkastosmeđe boje. Poznate su slike Andree Mantegne $u$ tutkalnoj temperi, osobito imitacije kamenih reljefa. ${ }^{32}$ Zbog mogućih kontakata s radionicom Mantegne u Mantovi, možda nije slučajno što upravo Correggio, koji prakticira tu tehniku, prvi konzistentno slika na obojenim preparacijama. ${ }^{33}$ Tutkalna tempera razmjerno je uobičajena u dolini rijeke Po, a sačuvana je i nedovršena Correggiova slika u toj tehnici (Alegorija Kreposti, prva polovica 16. stoljeća, galerija Doria Pamphilj, Rim). Nacrt je naznačen u ugljenu, a djelomični podslik izveden je crveno-smeđom bojom izravno na platnu koje je zbog starenja izvornih impregnacija i naknadnih intervencija poprimilo narančasto-smeđu boju. ${ }^{34}$ Istovremeno, na obojenim preparacijama na platnu rade i drugi sjevernotalijanski slikari. Filippo da Verona još oko 1514. godine slika na crveno-narančastoj preparaciji od olovne bijele i crvene zemlje. ${ }^{35}$ Smeđe preparacije $u$ Brescii 1526. godine uvodi Alessandro Bonvicino, poznat kao Moretto. Njegov učenik Giovanni Battista Moroni u drugoj polovici 16. stoljeća platna preparira žuto-smeđim i crveno-smeđim preparacijama, najčešće na tankom sloju gessa; učinkovitom tehnikom slikanja najbolje iskorištava tamne podloge. ${ }^{36}$

Iako se tradicija prepariranja platna gessom u Veneciji održala sve do kraja stoljeća, ${ }^{37}$ nedavnim je istraživanjima utvrđeno da Tizian i njegova radionica 1520-ih godina upotrebljavaju crveno-smeđe preparacije nanesene 


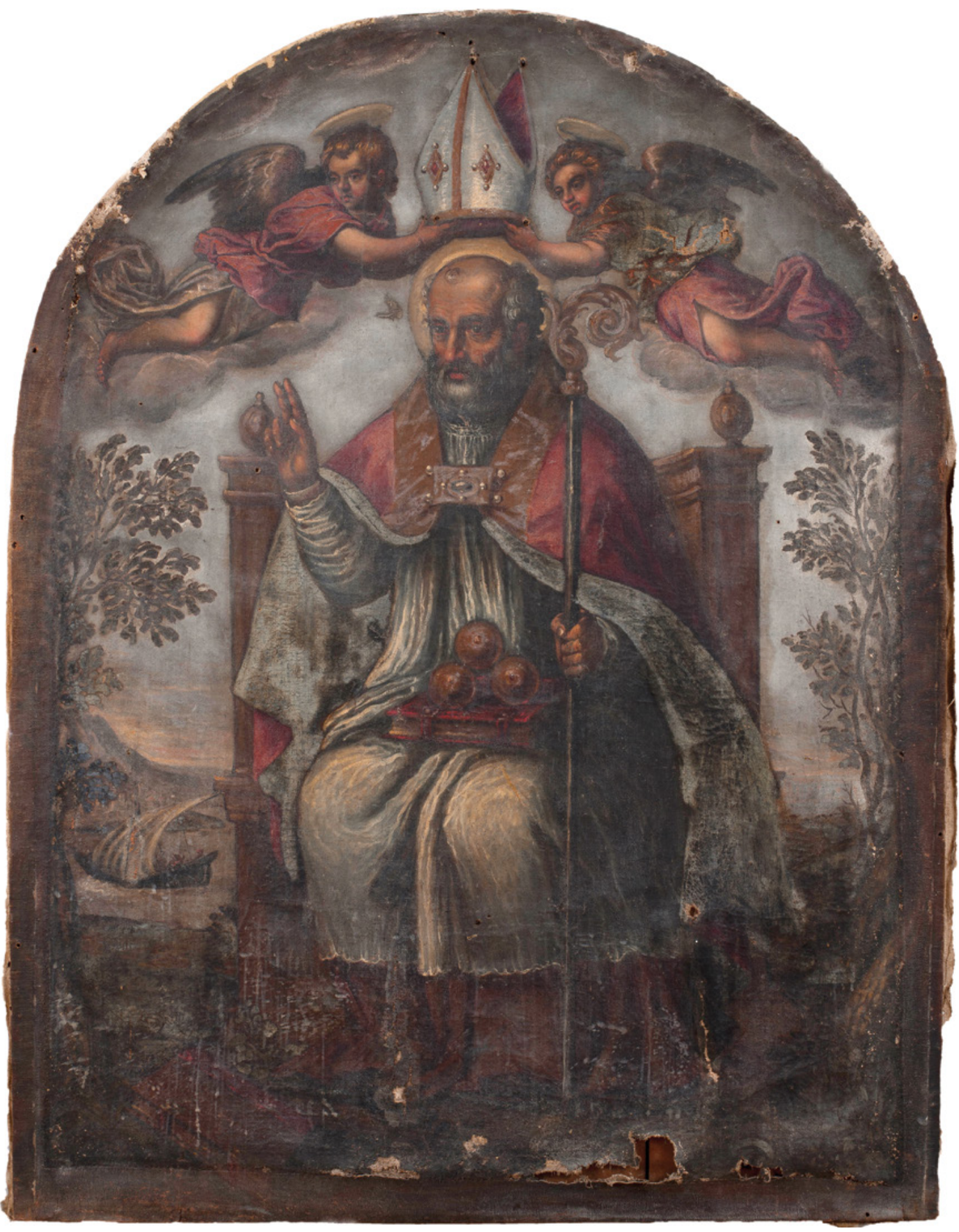

1. Giovanni Battista Argenti (?), Sv. Nikola, oko 1600., zatečeno stanje slike, Čiovo, crkva sv. Nikole (fototeka HRZ-a, snimio G. Tomljenović, 2015.)

Giovanni Battista Argenti (?), St. Nicholas, around 1600, as-found condition of the painting, Čiovo, church of St. Nicholas (Croatian Conservation Institute Photo Archive, photo by G. Tomljenović, 2015)

izravno na platno, što nije uobičajeno za slikarev opus..$^{38}$ Time je venecijanski majstor potvrđen kao jedan od pionira upotrebe toga tipa preparacije. Venecijanske slike s tamnim obojenim preparacijama potječu iz druge polovice 16. stoljeća i uglavnom se povezuju s radionicama i sljedbenicima Jacopa Bassana i Jacopa Tintoretta; crne i tamne crveno-smeđe preparacije, ponekad s tragovima gessa na platnu, utvrđene su na djelima obojice slikara. ${ }^{39}$ Sličan prijelazni tip preparacije, tamnosive boje na tankom sloju bijele osnove (najvjerojatnije gessa), u Dalmaciji je zabilježen na oltarnoj slici Sv. Nikola, pripisanoj mletačkom slikaru Giovanniju Battisti Argentiju (oko 1600., 

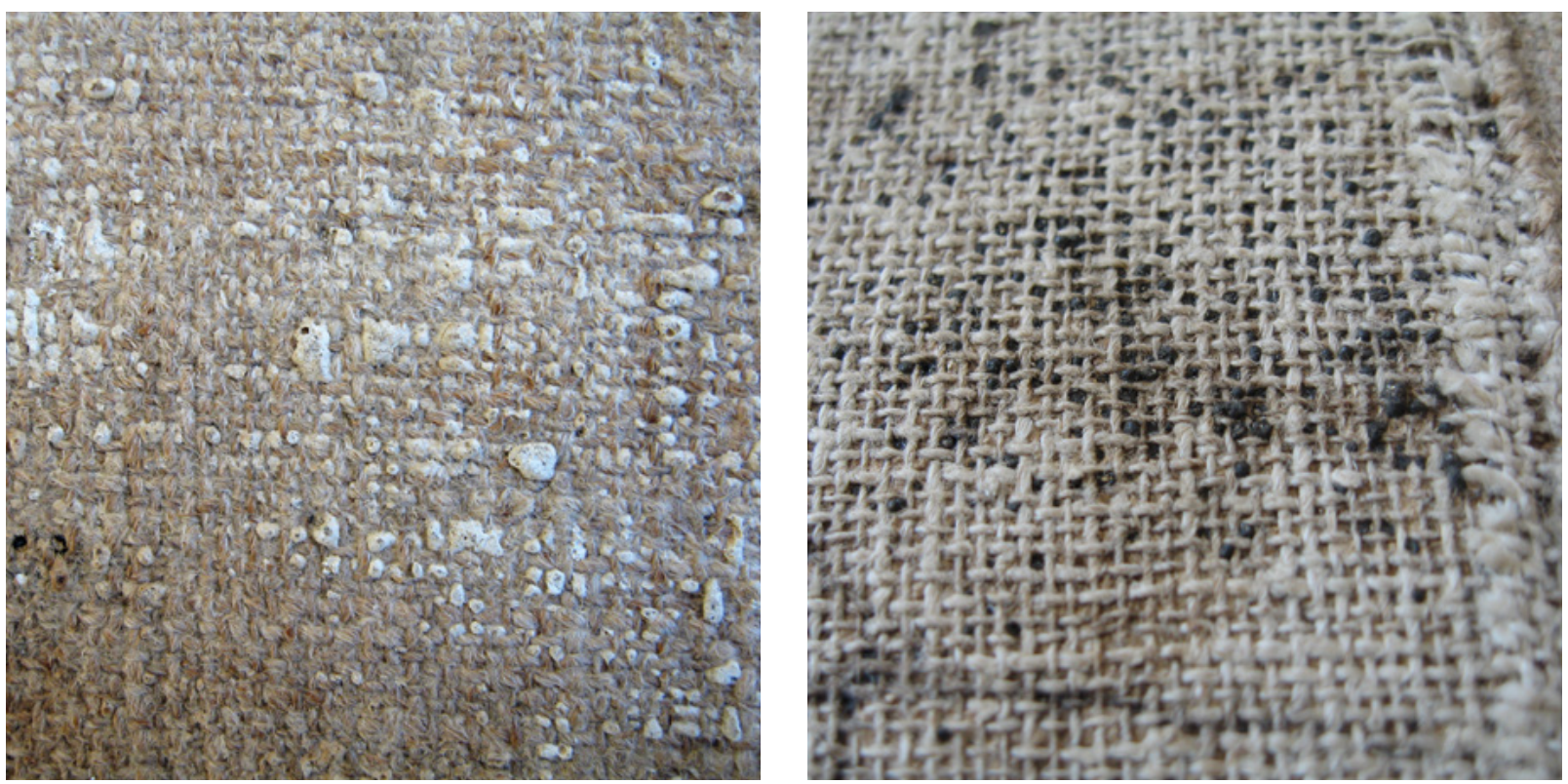

2. Giovanni Battista Argenti (?), Sv. Nikola, oko 1600., detalji poleđine platna s bijelom, vjerojatno gipsanom preparacijom i tamnosivom imprimaturom - obje smjese prodrle su kroz očice između niti, Čiovo, crkva sv. Nikole (fototeka HRZ-a, snimila J. Zagora, 2016.) Giovanni Battista Argenti (?), St. Nicholas, around 1600, details of the back of the canvas with a white preparation, probably gypsum, and a darkgrey imprimatura - both mixtures penetrated through the interstices between the threads, Ciovo, church of St. Nicholas (Croatian Conservation Institute Photo Archive, photo by J. Zagora, 2016)

crkva sv. Nikole, Čiovo, ${ }^{40}$ sl. 1,2 i 3). Na sjeveru Italije $u$ prvoj polovici 16. stoljeća dokumentirane su i svijetle pigmentirane preparacije s gipsom kao punilom, neutvrđenog veziva, te uljene na bazi olovne bijele $u$ regiji Veneto, ali i u Firenci. ${ }^{41}$ Obojene preparacije različitih boja, sastava i stratigrafije nastavljaju se koristiti i prilagođavati u iduća dva stoljeća.

\section{7. stoljeće i porijeklo crvenih preparacija u 18. stoljeću - Bologna ili Venecija?}

Slikarski traktati u Europi iz 17. stoljeća opisuju uljene preparacije s punilom pretežito od gline, odnosno lončarske zemlje nožem nanesene u nekoliko slojeva na platno impregnirano tutkalom ili pastom od brašna. ${ }^{42}$ Istraživanja pokazuju da su u talijanskom slikarstvu ranog 17 . stoljeća u upotrebi sive i (crvenkasto)smeđe jednoslojne uljene preparacije na bazi kalcijeva karbonata; Caravaggio je, primjerice, koristio svijetlosmeđu s dodatkom olovne bijele i zemljanih pigmenata. ${ }^{43}$ Hellen Glanville potvrđuje da je u preparacijama slika nastalih u središnjoj Italiji u 17. stoljeću kreda prisutna u znatnim udjelima. ${ }^{44}$ Premda dokumentira i preparacije sastavljene pretežito od olovne bijele, Elisabeth Martin primjećuje da su smeđe uljene preparacije od zemljanih pigmenata, često $\mathrm{s}$ kredom ili olovnom bijelom, raširene $u$ talijanskom slikarstvu kraja 16. i 17. stoljeća. Znatan dio umjetnika čija su djela obuhvaćena istraživanjem pripada bolonjskoj školi, uključujući slikare obitelji Carracci, Domenichina, Guida Renija i Guercina, a Bologna se još ističe po širokoj upotrebi sijene. ${ }^{45}$ Slično zaključuje i Mojmír Hamsík, utvrdivši da su u Italiji 17. stoljeća najčešće tamnosmeđe preparacije, često s dodatkom olovne bijele te krede $\mathrm{i}$ gipsa, a crvene i crveno-smeđe čine znatno manji udio. Na slikama iz sjeverne Italije i Venecije pronalazi i svijetle, žute oker preparacije, dok one vrlo tamnih, gotovo crnih nijansi potječu s područja Napulja (ponekad sa sivim podslikom). Vezivo je, čini se, pretežito emulzijskog tipa: ulje je glavni sastojak, no često s dodatkom

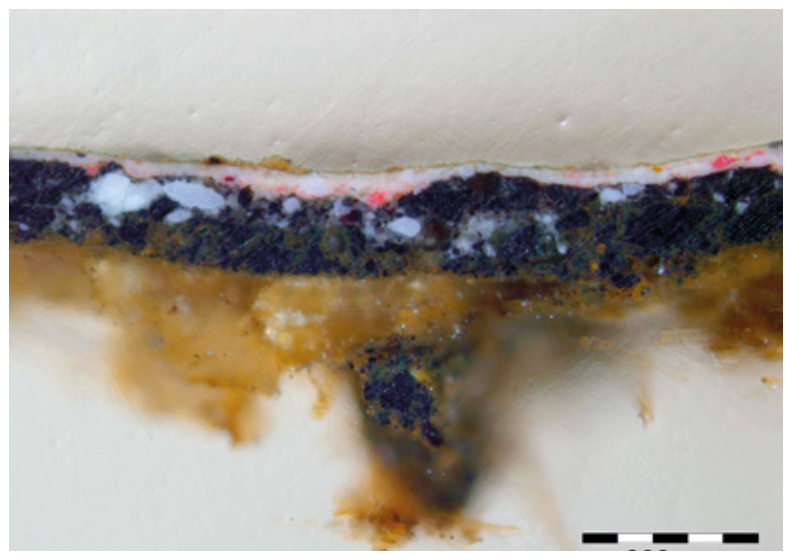

3. Giovanni Battista Argenti (?), Sv. Nikola, oko 1600., mikropresjek slikanog sloja s vjerojatno gipsanom preparacijom i tamnosivom imprimaturom (uzorak inkarnata s lica lijevog anđela), Čiovo, crkva sv. Nikole (fototeka HRZ-a, snimila M. Jelinčić, 2016.)

Giovanni Battista Argenti (?), St. Nicholas, around 1600, microsection of the painted layer with the (probably) gypsum preparation and the dark-grey imprimatura (sample of the flesh colour from the left angel's face), Ciovo, church of St. Nicholas (Croatian Conservation Institute Photo Archive, photo by M. Jelinčić, 2016) 


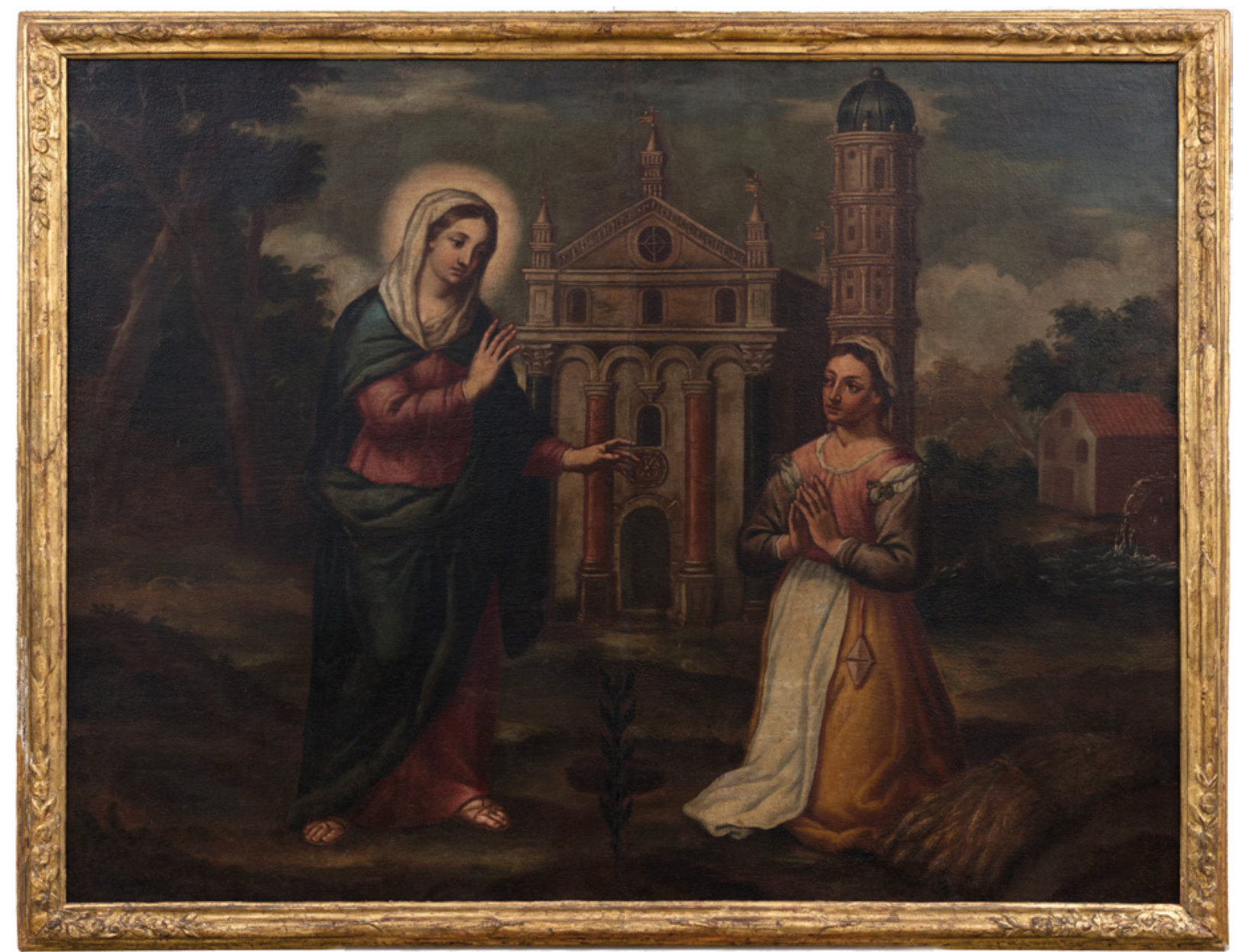

4. Nepoznati slikar, Gospa od Karavaja, kraj 17. stoljeća, slika nakon konzervatorsko-restauratorskog zahvata, Šibenik, katedrala (fototeka HRZ-a, snimio J. Kliska, 2016.)

Unknown painter, Our Lady of Caravaggio, end of 17th c., the painting after conservation, Šibenik, cathedral (Croatian Conservation Institute Photo Archive, photo by J. Kliska, 2016)

proteinskog veziva. ${ }^{46}$ Zanimljivo, $u$ kasnijem razdoblju stvaralaštva Palme mlađeg (između 1603. i 1622. godine) zabilježena je tamnosmeđa dvoslojna preparacija od tutkalno-uljne emulzije i pretežito zemljanih pigmenata. ${ }^{47}$ Među restauriranim slikama u galeriji Doria Pamphilj u Rimu, omjer smeđih i crveno-smeđih preparacija slika iz 17. stoljeća iz raznih talijanskih regija je podjednak. ${ }^{48}$

Unatoč tradicionalnim pretpostavkama o talijanskom porijeklu karakterističnih crvenih preparacija koje su se u 18. stoljeću proširile po cijeloj Europi, istražujući bibliografiju stječe se dojam da njihovo porijeklo nije razjašnjeno, niti im je posvećena veća znanstvena pozornost. U prilog teorijama o talijanskom porijeklu, Maartje Stols-Witlox zaključuje da se u recepturama preparacija između 1550. i 1900. godine crvenkaste preparacije savjetuju pretežito za platno i češće su u južnoeuropskim receptima. ${ }^{49}$ Iako, nažalost bez uvjerljive reference, ista autorica navodi da se preparacije od crvenog okera najprije pojavljuju na bolonjskim slikama na platnu malo prije 1600 . godine, a tijekom 17. stoljeća postaju najčešći tip u Italiji, odakle se šire u Španjolsku (carravaggisti), Češku, Njemačku i Au- striju. ${ }^{50} \mathrm{U}$ francuskom, nizozemskom i flamanskom slikarstvu 17. stoljeća uglavnom se povezuju s talijanskom praksom pojedinih slikara. ${ }^{51}$ Iznenađuje to što je najraniji primjer koji sam uspjela pronaći, Sv. Jeronim Maartena de Vosa, nastao još 1580-ih godina (Muzej Maagdenhuis, Antwerpen). ${ }^{52}$ Teza o bolonjskom porijeklu ipak je zanimljiva: Bologna je, naime, poznata po crvenim opekama. ${ }^{53}$ Mary Philadelphia Merrifield spominje crvenu zemlju iz toga grada, koju su za prepariranje katkad upotrebljavali Tizian i Guercino, pripadnik bolonjske škole. ${ }^{54}$ Prema bilješkama slikara amatera Richarda Symondsa iz sredine 17. stoljeća, zemlja za izradu opeka dobra je za prepariranje platna; smjese na bazi crvene zemlje upotrebljavali su umjetnici u Rimu: Giovanni Angelo Canini i slikari bolonjske obitelji Carracci. ${ }^{55}$ Uvođenje tamnih preparacija Merrifield pripisuje upravo slikarima obitelji Carracci, a Palmu mlađeg navodi kao zaslužnog za njihovo širenje u Veneciju. ${ }^{56}$ Premda ta teza odavno ne stoji, preparacije slikara bolonjske škole i dalje su zanimljive za istraživanje, kao i poveznice crvenih preparacija s Bolognom i Rimom te Venecijom. ${ }^{57}$ Crvene slikarske preparacije i cr- 


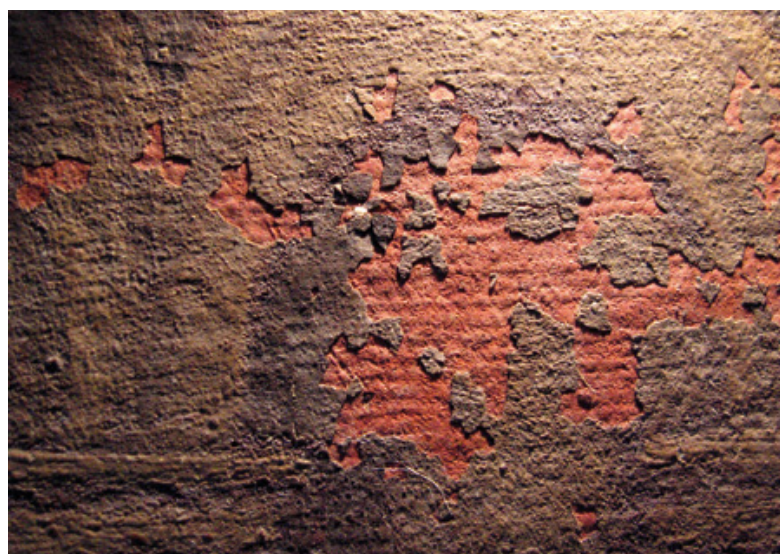

5. Nepoznati slikar, Gospa od Karavaja, kraj 17. stoljeća, detalj oštećenja slikanog sloja pod kosim svjetlom s vidljivim donjim slojem preparacije, Šibenik, katedrala (fototeka HRZ-a, snimila J. Zagora, 2014.)

Unknown painter, Our Lady of Caravaggio, end of 17th c., detail of a damaged painted layer under raking light, with a visible bottom layer of preparation, Šibenik, cathedral (Croatian Conservation Institute Photo Archive, photo by J. Zagora, 2014)

veni zemljani pigmenti tradicionalno se vezuju upravo uz Veneciju i regiju Veneto, osobito u 18. stoljeću.

Venecijanska crvena (Venetian red) je pigment od zemlje koja se, kako navodi Merrifield, nabavljala u Veroni, a koristila se i za izradu opeka od kojih su sazdane broj-

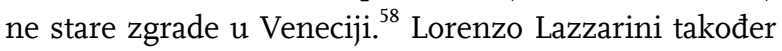
navodi nalazišta žute i crvene zemlje u okolici Verone terra rossa ili rosso veneziano iskopava se u mjestu Badia di Calavena još od antičkih vremena, a sastoji se od 70\% hematita i $30 \%$ gline. ${ }^{59}$ Izraz terra rosa neki autori povezuju isključivo s venecijanskom crvenom, a navodi se i mogućnost nalazišta crvenog okera u Veneciji. Ipak, terminologija prirodnih i sintetskih crvenih željeznih oksida vrlo je zbunjujuća; brojni nazivi, pa tako i venecijanska crvena, koriste se za obje varijante i najčešće se odnose na nijansu. Svakako, izraz je izvorno označavao prirodni željezni oksid ili crveni hematit, a poslije se, vjerojatno nakon iscrpljivanja prirodnih izvora, odnosi na sintetski proizvedene željezne okside koji imitiraju izvornu nijansu. ${ }^{60}$ Uobičajio se tek $u$ 18. stoljeću, a čini se da su ga tada skovali engleski pisci kako bi opisali boju koja se često viđa $u$ venecijanskom slikarstvu. ${ }^{61}$ Sva navedena objašnjenja odnose se na pigment za izradu boja. Iako je lokalna dostupnost izuzetno važan čimbenik odabira punila i pigmenata za izradu povijesnih preparacija, ${ }^{62} \mathrm{za}$ sada nigdje nisam pronašla izravne dokaze o povezanosti spomenutih nalazišta crvenog okera s venecijanskim crvenim preparacijama.

O praksi venecijanskog slikarstva s kraja 17. stoljeća svjedoče zapisi Giovannija Battiste Volpata (Bassano, 1633. - 1707.). Premda piše da su za izradu preparacija dobre sve zemlje ovisno o ukusu, Volpato upotrebljava lončarsku

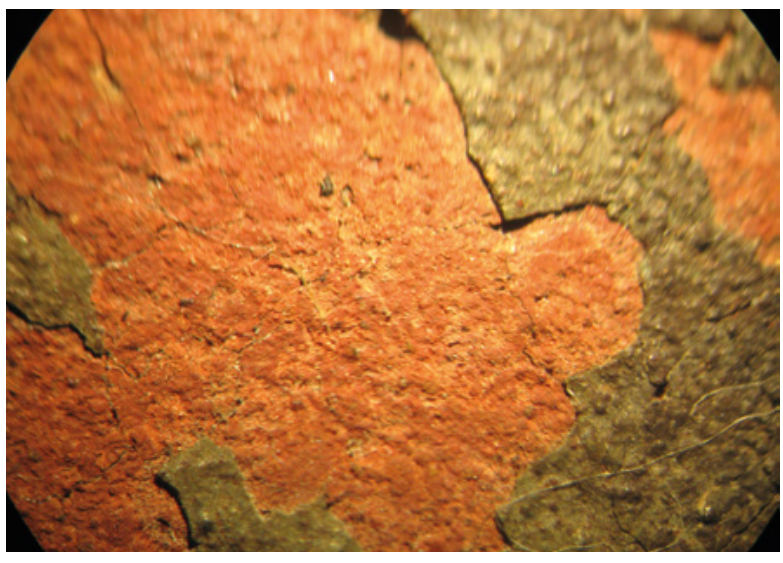

6. Nepoznati slikar, Gospa od Karavaja, kraj 17. stoljeća, detalj oštećenja slikanog sloja pod uvećanjem - vide se donji crveni sloj i ostaci gornjeg sloja preparacije narančaste nijanse, Šibenik, katedrala (fototeka HRZ-a, snimila J. Zagora, 2014.)

Unknown painter, Our Lady of Caravaggio, end of 17th c., detail of the damaged painted layer under magnification - visible are a bottom red layer and remains of an upper layer of an orange-toned preparation, Šibenik, cathedral (Croatian Conservation Institute Photo Archive, photo by J. Zagora, 2014)

zemlju, crvenu zemlju i malo umbre. ${ }^{63}$ Ne možemo znati kakvu bi točno nijansu dala ta kombinacija, no njegov vrlo čitani tekst mogao je utjecati na usvajanje preparacija crvene boje u Veneciji 18. stoljeća. Ne raspravljajući o njihovu porijeklu, Stefano Marconi navodi da se jednoslojne crvene i crveno-smeđe preparacije zrnate teksture, sastavljene pretežito od crvenog okera (često s dodatkom minija), nastavljaju usvajati u talijanskom slikarstvu 18. stoljeća, osobito venecijanskom. Mogu se vidjeti na slikama Canaletta, Guardija, Tiepola, Giovannija Battiste Piazzette i Giovannija Antonija Pellegrinija. ${ }^{64}$ Hamsík potvrđuje da

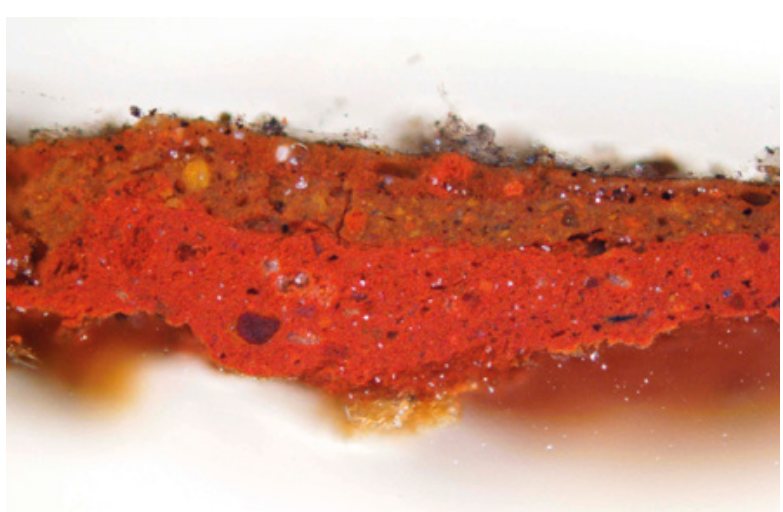

7. Nepoznati slikar, Gospa od Karavaja, kraj 17. stoljeća, mikropresjek slikanog sloja s dvostrukom preparacijom (uzorak oslika svetišta lijevo od ramena Giannette), Šibenik, katedrala (fototeka HRZ-a, snimila M. Jelinčić, 2014.)

Unknown painter, Our Lady of Caravaggio, end of 17th c., microsection of the painted layer with a double preparation (sample of the painting of the sanctuary left of Giannetta's shoulder), Šibenik, cathedral (Croatian Conservation Institute Photo Archive, photo by M. Jelinčić, 2014) 


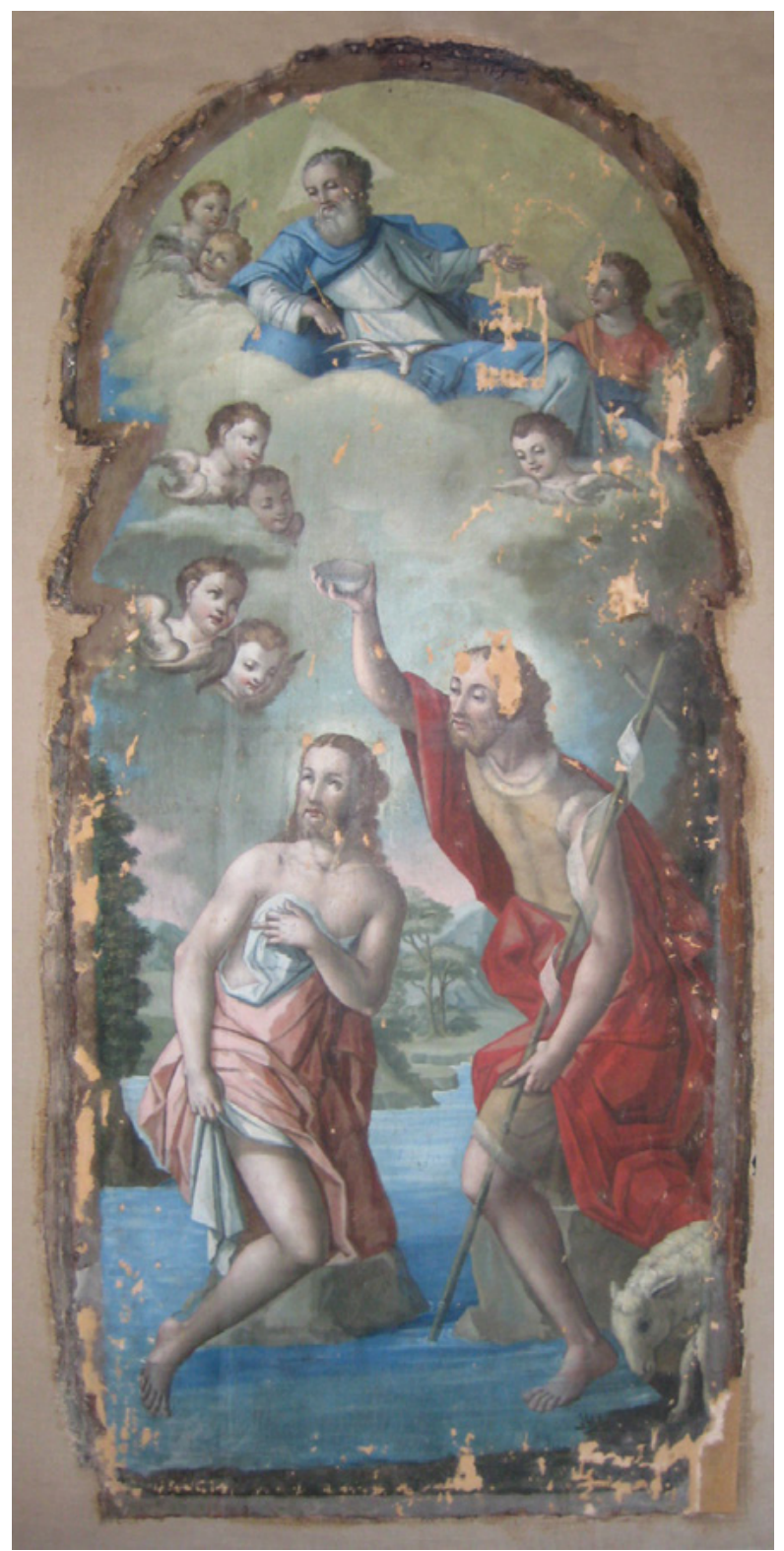

8. Nepoznati slikar, Krštenje Krista, 18. stoljeće, slika tijekom zahvata, Gornje Selo (Šolta), crkva sv. Ivana Krstitelja (fototeka HRZ-a, snimio J. Delić, 2014.)

Unknown painter, The Baptism of Christ, 18th c., the painting during conservation, Gornje Selo (Šolta), church of St. John the Baptist (Croatian Conservation Institute Photo Archive, photo by J. Delić, 2014)

u 18. stoljeću dominiraju intenzivno crvene preparacije; u drugoj polovici stoljeća boja naginje prema jarko narančastim nijansama, osobito na području Venecije (Gaspare Diziani, Francesco Fontebasso). ${ }^{65}$ Moglo bi se navesti još mnogo pojedinačnih primjera; svakako, čini se da su pojam i termin tradicionalne venecijanske crvene preparacije vezani uz 18. stoljeće, ${ }^{66}$ kao i pigment venecijanska crvena. Zanimljivo je spomenuti i to da francuski slikari 18. stoljeća upotrebljavaju čisti crveni oker (s dodatkom barita) za donje slojeve preparacija, ${ }^{67}$ a crvene preparacije od gotovo čistih željeznih oksida dokumentirane su i na slikama talijanskih autora s kraja 17. i iz 18. stoljeća u Dalmaciji. ${ }^{68}$ Iako još nigdje nisam pronašla eksplicitan dokaz, možda je boja tada određena (i) dostupnošću čišćih željeznih oksida.

Iz svega iznesenog razvidno je da su diljem Italije utvrđene pretežito smeđe preparacije različitih sastava na bazi zemljanih pigmenata s kraja 16. i iz 17. stoljeća. Pitanje veziva zahtijeva dodatnu pozornost - prema povijesnim zapisima i dosadašnjim analizama, podrazumijeva se da je vezivo obojenih preparacija talijanskih slika iz 17. i 18. stoljeća u većini slučajeva ulje, premda se u restauratorskoj praksi često nailazi na vrlo hidrofilne preparacije. ${ }^{69}$ Indicije o bolonjskom porijeklu crvenih preparacija potkraj 16 . stoljeća tek treba ispitati, to više što se, čini se, istovremeno pojavljuju i na sjeveru Europe. Tradicionalne teorije o Veneciji kao izvorištu njihova širenja nisu neutemeljene, no nisu ni dovoljno analitički potkrijepljene. Neosporno je da su crvene preparacije česte na djelima slikara iz 18. stoljeća iz regije Veneto, no pitanje je gdje je proces prelaska počeo i što ga je pokrenulo, koliko je na to utjecala lokalna dostupnost pigmenata ili možda nova tehnologija obrade željeznih oksida te estetska preferencija crvenih podloga za slikanje. Iako su objavljene brojne studije posvećene tehnologiji izrade pojedinačnih djela, u Italiji još nema većeg, sustavnog istraživanja slikarskih preparacija, osobito onih u Veneciji 17. i 18. stoljeća. ${ }^{70}$ Porijeklo preparacija intenzivne crvene boje koje $u$ talijanskom i europskom slikarstvu 18. stoljeća istiskuju sve ostale nijanse ostaje nejasno, kao i vrijeme i kontekst njihove pojave. Za početak, bilo bi zanimljivo utvrditi i analizirati najranije primjere crvenih preparacija u Italiji, ali i u Dalmaciji, ${ }^{71}$ premda nije potpuno jasno ni kada nestaju, ustupivši mjesto onima sa svijetlim gornjim slojem tijekom povratka na bijele preparacije $u$ kasnom 18 . stoljeću. ${ }^{72}$

\section{Dvostruke preparacije - o porijeklu, pojavi u Italiji i razlozima uvođenja}

Dvostruke preparacije, odnosno obojene uljene preparacije izrađene od dva sloja (osnove) različitih boja, ${ }^{73}$ vjerojatno se pojavljuju u 16. stoljeću u sjevernoj Nizozemskoj i Flandriji, a najčešće se sastoje od sloja sive boje nanesenog na crveni sloj. ${ }^{74}$ Tijekom 17. stoljeća postaju vrlo popularne i šire se u Francusku, Englesku i druge dijelove Europe. Kao i u sjevernoj Nizozemskoj, u Francuskoj 17. stoljeća dvostruke preparacije najčešće imaju donji sloj crvene ili žute oker boje na bazi krede ili zemljanih pigmenata prekriven sivim gornjim slojem na bazi olovne bijele. ${ }^{75}$ Ipak, pigmentacija slojeva varira, čak i unutar opusa pojedinih slikara, primjerice Rubensa, Van Dycka i Rembrandta; u 18. su stoljeću i u drugim dijelovima Europe zabilježeni gornji slojevi smeđe, oker, žute, ružičasto-sive i crvene boje. $^{76}$ Dvoslojne preparacije opisuju i sjevernoeuropski autori slikarskih traktata od 17. stoljeća. ${ }^{77}$ Premda kao vezivo obaju slojeva traktati uvijek spominju ulje, u nekoliko je slučajeva u donjem sloju utvrđeno proteinsko 


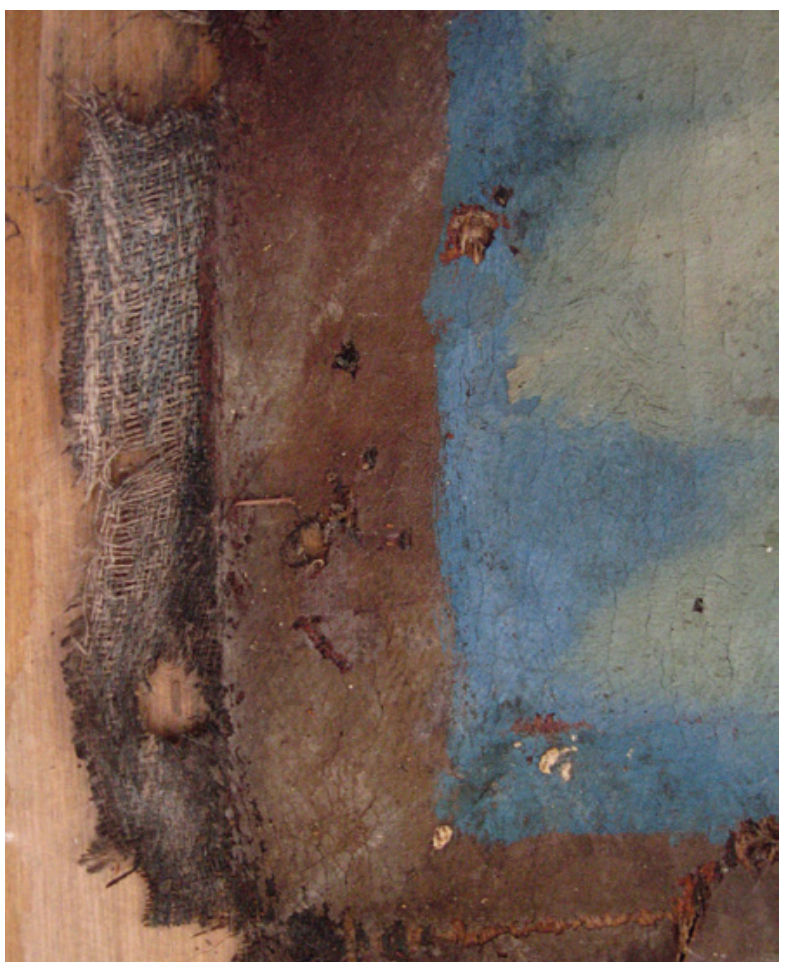

9. Nepoznati slikar, Krštenje Krista, 18. stoljeće, detalj donjeg lijevog ruba slike (vidljiv je sivi gornji sloj dvostruke preparacije), Gornje Selo (Šolta), crkva sv. Ivana Krstitelja (fototeka HRZ-a, snimila J. Zagora, 2014.)

Unknown painter, The Baptism of Christ, 18th c., detail of the bottom left edge of the painting (visible is a grey upper layer of a double preparation), Gornje Selo (Šolta), church of St. John the Baptist (Croatian Conservation Institute Photo Archive, photo by J. Zagora, 2014)

vezivo, a uz to su na nekim slikama između i iznad slojeva preparacije detektirani izolacijski slojevi na bazi smola, odnosno tutkala. ${ }^{78}$

Nekoliko primjera dvostrukih preparacija vrlo različite pigmentacije slojeva utvrđeno je na djelima talijanskih slikara iz 17. stoljeća. Slično europskim dvostrukim, ali i jednoslojnim preparacijama toga doba $u$ Italiji, donji slojevi pretežito se sastoje od zemljanih pigmenata i/ili krede, dok gornji sadrže olovnu bijelu sa zemljanim pigmentima. Na preparaciji s tamnosmeđim donjim i sivim gornjim slojem Caravaggio je 1602. godine naslikao ciklus slika za crkvu San Luigi dei Francesi u Rimu. ${ }^{79}$ Nepoznati autor rimske škole oko 1612. godine slikao je na sloju bež boje iznad narančasto-crvenog, ${ }^{80}$ dok Orazio Gentileschi u Parizu usvaja preparaciju s donjim crvenim i gornjim sivim slojem, karakterističnu za pariške umjetnike toga doba. Sredinom stoljeća Guercino radi na raznolikim dvostrukim preparacijama - od onih s roskastim povrh sivog ili smeđeg sloja do smeđe dvostruke preparacije s nešto svjetlijim gornjim slojem. ${ }^{81}$ Iznimno složena stratigrafija dokumentirana je na djelu bolonjske slikarice Elisabette Sirani (Bogorodica doji Dijete, 1663., Nacionalna galerija, Prag) - međusloj crvenog laka utvrđen je između dvaju

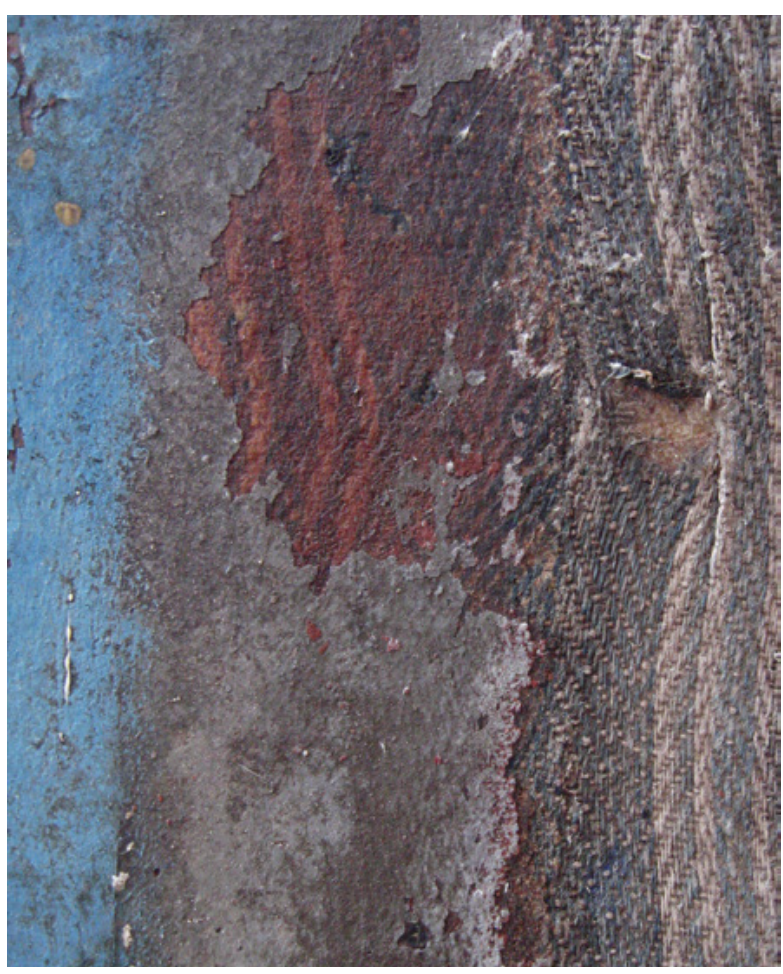

10. Nepoznati slikar, Krštenje Krista, 18. stoljeće, detalj desnog ruba slike (u oštećenju je vidljiv crveni donji sloj dvostruke preparacije), Gornje Selo (Šolta), crkva sv. Ivana Krstitelja (fototeka HRZ-a, snimila J. Zagora, 2014.)

Unknown painter, The Baptism of Christ, 18th c., detail of the right edge of the painting (in the damaged spot there is a visible red bottom layer of the double preparation), Gornje Selo (Šolta), church of St. John the Baptist (Croatian Conservation Institute Photo Archive, photo by J. Zagora, 2014)

slojeva smeđe preparacije, povrh čega je dvoslojni sivi podslik. $^{82}$ Iako su gotovo svi navedeni autori djelovali u Rimu (barem u prvom dijelu karijere), uzorak je nedovoljan i preraznolik za uspostavljanje bilo kakvih poveznica boje i sastava preparacije s autorom i mjestom nastanka slika.

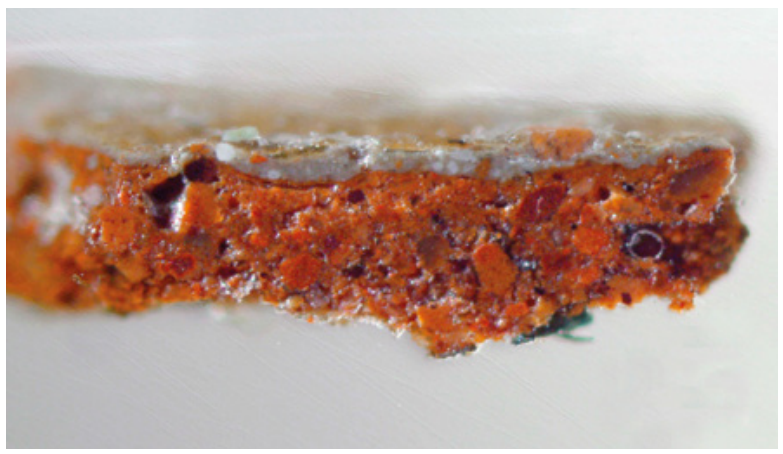

11. Nepoznati slikar, Krštenje Krista, 18. stoljeće, mikropresjek uzorka dvostruke preparacije (lijevi rub slike), Gornje Selo (Šolta), crkva sv. Ivana Krstitelja (fototeka HRZ-a, snimila M. Jelinčić, 2015. Unknown painter, The Baptism of Christ, 18th c., microsection of the double preparation sample (left edge of the painting), Gornje Selo (Šolta), church of St. John the Baptist (Croatian Conservation Institute Photo Archive, photo by M. Jelinčić, 2015) 
Noviji pregledi, $\mathrm{k}$ tome, talijanske dvostruke preparacije spominju samo u kontekstu 18. stoljeća i uglavnom ih povezuju s venecijanskim slikarstvom. Stols-Witlox navodi da su na dvostrukim uljenim preparacijama s gornjim slojem na bazi olovne bijele slikali Guardi, Canaletto i Tiepolo te Pompeo Batoni. ${ }^{83}$ Zanimljivo, čini se da su se Canalettove dvostruke preparacije razvile iz podslikavanja - u ranijem razdoblju, slikar na crvenu ili narančastu preparaciju nanosi blokove podslika (sivi ispod prikaza neba i vode, crveni ili narančasti ispod zgrada), u drugoj fazi uvodi blijedi bež i sivi podslik, a poslije (oko 1730.) na cijelu površinu platna nanosi i drugi sloj preparacije pretežito blijede bež, katkad blijede sive ili žuto-smeđe boje, pretežito sa sivim podslikom. ${ }^{84}$ U Engleskoj, Canaletto radi na kupovnim platnima s tipičnom engleskom svijetlom dvostrukom preparacijom. ${ }^{85}$ Postoje indicije da je na već prepariranim platnima radio i u Veneciji, gdje upotrebljava isključivo crvene i narančaste preparacije. ${ }^{86}$ Dva tipa dvostrukih preparacija utvrđena su na slikama venecijanske provenijencije $u$ Dalmaciji. Slika nepoznatog autora s prikazom Gospe od Karavaja, vjerojatno naslikana potkraj 17. stoljeća, pronađena je u šibenskoj katedrali (sl. 4). ${ }^{87}$ Donji sloj preparacije na bazi je hidrofilnog veziva i narančasto-crvene je boje, a gornji boje narančasto-žutog okera (sl. 5, 6 i 7). Oba sloja sastoje se pretežito od željeznih oksida. ${ }^{88}$ Oltarna pala Krštenje Krista iz župne crkve sv. Ivana Krstitelja u Gornjem Selu na otoku Šolti djelo je nepoznatog umjetnika iz 18. stoljeća (sl. 8). ${ }^{89}$ Iznad narančasto-crvenog donjeg sloja nanesen je drugi, tanji sloj svijetlosive boje na cijelu površinu slike (sl. 9, 10 i 11). Dvostruke preparacije na djelima talijanskih slikara očigledno zahtijevaju više pozornosti, osobito se to odnosi na okolnosti njihove pojave u 17. stoljeću.

Većina današnjih autora smatra da su se dvostruke preparacije pojavile kao ekonomično rješenje problema prosijavanja smeđih i crvenih preparacija kroz uljenu boju koja starenjem postaje providnija, što doprinosi nepoželjnom tamnjenju slike. Nanošenjem tankog svijetlog sloja baziranog na skupljoj olovnoj bijeloj na deblji podložni sloj od jeftinih, lako dostupnih zemljanih pigmenata, slikari su možda sprječavali tamnjenje kolorita zbog prosijavanja preparacije kroz uljenu boju koja starenjem postaje transparentnija, čega su bili svjesni i tada. De Mayerne, k tome, preporučuje oker u donjim slojevima zbog smanjenja troškova. ${ }^{90}$ Ipak, to ne može vrijediti u slučajevima u kojima je i gornji sloj na bazi zemljanih pigmenata. Prema drugoj teoriji, slikari 18. stoljeća svjesno su kombinirali slojeve preparacije različitih boja zbog vizualne interakcije; tekst anonimnog nizozemskog autora iz 1777. godine objašnjava da se nanošenjem sivog sloja na crveni podložni sloj postiže odgovarajuća crvenkasto-siva nijansa, koja se uglavnom slaže sa svim bojama u slikarstvu. ${ }^{91}$ To, ipak, ne može vrijediti u brojnim slučajevima u kojima je gornji sloj predebeo i neprovidan. Izvjesno je da su neki slikari kupovali već preparirana platna, a sami nanosili dodatni, drugačiji sloj (navela sam primjer Canaletta), premda su prepariranje potpuno obavljale i specijalizirane radionice za izradu preparacija ili pak sami slikari. ${ }^{92}$

Svaka od navedenih teorija vjerojatno je primjenjiva $u$ nekim slikarskim krugovima, no tema je još uvijek predmet istraživanja. U eseju o porijeklu nizozemskih dvostrukih preparacija s crvenim donjim slojem, Karin Groen iznosi i zanimljive poveznice s iznenađujuće dugom tradicijom crvenih podloga $u$ raznim granama umjetnosti $u$ Nizozemskoj, uključujući zidno slikarstvo te polikromiranu i pozlaćenu kamenu skulpturu, gdje se upotrebljavaju još od 15 . stoljeća. ${ }^{93}$

\section{Podslik s funkcijom preparacije - jedinstven primjer u uljenom slikarstvu na platnu ili nedovoljno istražena tema?}

Izuzetno je zanimljiva tehnologija izrade slike Gospa Bezgrešna ${ }^{94}$ koju je za glavni oltar šibenske crkve sv. Nediljice (predio Crnica) naslikao venecijanski umjetnik Angelo Mancini 1609. godine (sl. 12). ${ }^{95} \mathrm{Na}$ platno (vjerojatno tutkaljeno) nije nanesen homogeni sloj koji bi se mogao opisati kao obojena preparacija; boja varira od tamne crvenkastosmeđe (plava pozadina i mandorla, sl. 13. 15 i 16) do okera (Gospina odjeća, sl. 14), što više nalikuje na svojevrsni podslik, pripremnu skicu uljanom bojom. ${ }^{96} \mathrm{U}$ jednom se uzorku uočavaju i smeđi i oker sloj. Nanosi su, $\mathrm{k}$ tome, u cjelini izuzetno tanki, gotovo lazurni, iako i debljina prilično varira. Moglo bi se reći da je riječ o podsliku s funkcijom tanke preparacije, odnosno obojene slikarske podloge. Osim u drugom poglavlju navedenih primjera lokalnih, odnosno imprimatura varirajuće boje i Correggiova crveno-smeđeg podslika na (impregniranom) platnu $\mathrm{u}$ tehnici tutkalne tempere, $\mathrm{u}$ ovom su kontekstu vrlo zanimljive i bilješke Nica van Houta o slikama Baroccija, Rubensa, Velázqueza, Lesueura i Canaletta na kojima su otkrivene velike površine podslikane različitim bojama. Tako je pozadina oslika Baroccijeve slike Polaganje $u$ grob (oko 1579. - 1582., Chiesa della Croce, Senigallia) podslikana u zonama različitih boja, dok Velázquezova Venera pred zrcalom (oko 1647. - 1651., Nacionalna galerija, London) s preparacijom od olovne bijele ima podslik od crvenog okera svugdje osim ispod lika Venere. ${ }^{97}$ Canalettove tehnike podslikavanja već sam navela, kao i tamne preparacije sa sivim podslikom na djelima napuljskih slikara, kojima se može pribrojiti i Krajolik sa zasjedom Francesca Grazianija (druga polovica 17. stoljeća, galerija Doria Pamphilj, Rim) naslikan na crveno-smeđoj preparaciji sa žućkastim podslikom u predjelu neba. ${ }^{98}$ Spomenut ću i oltarnu palu Krštenje Krista i Gospa od Karmela Francesca Fedrigazzija (datirana u rano 18. stoljeće, župna crkva sv. Mihovila, Kostanje) na crveno-smeđoj preparaciji s lokalnim podslikom na bazi olovne bijele u gornjem dijelu, gdje je prikaz neba i Bogorodice. ${ }^{99}$ Podslikane zone 


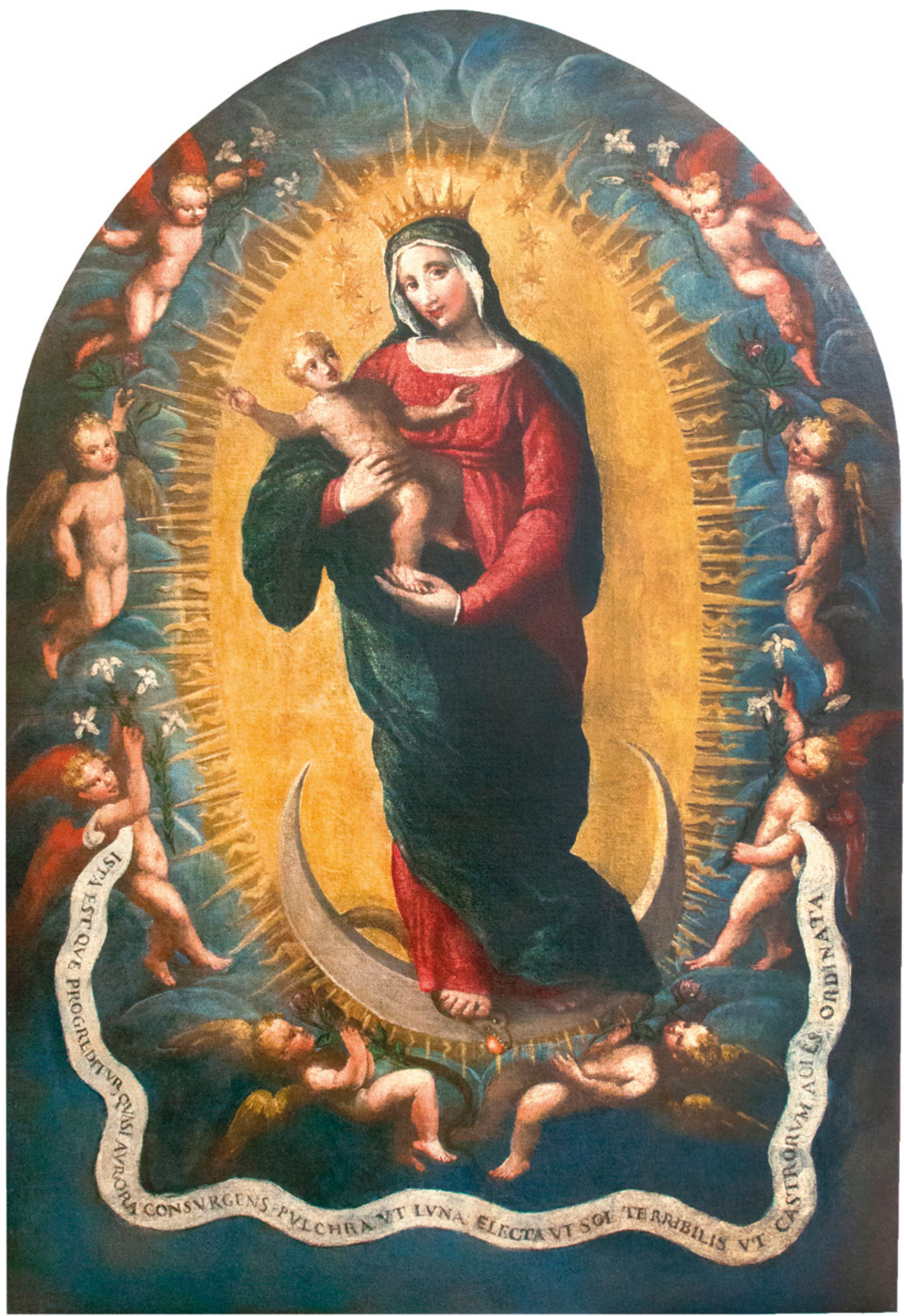

12. Angelo Mancini, Bogorodica Bezgrešna, 1609., slika nakon konzervatorsko-restauratorskog zahvata, Šibenik, crkva sv. Nediljice na predjelu Crnica (fototeka HRZ-a, snimio D. Gazde, 2013.)

Angelo Mancini, The Immaculate Virgin, 1609, the painting after conservation, Šibenik, church of St. Domenica in the Crnica area (Croatian Conservation Institute Photo Archive, photo by D. Gazde, 2013) 


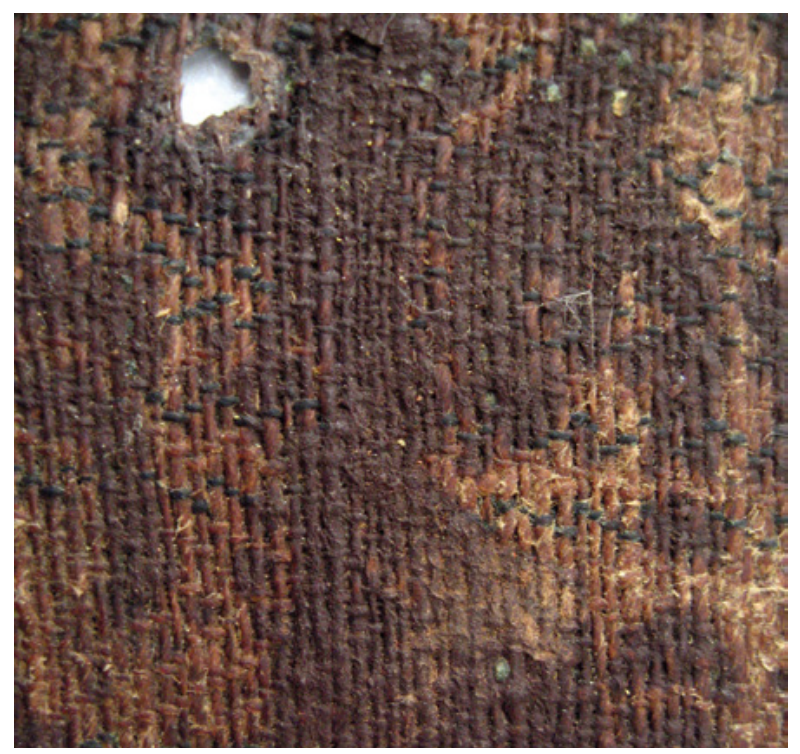

13. Angelo Mancini, Bogorodica Bezgrešna, 1609., detalj poleđine platna s tamnosmeđim podslikom/obojenom preparacijom (smjesa je prodrla na poleđinu slike u predjelu podokvira), Šibenik, crkva sv. Nediljice na predjelu Crnica (fototeka HRZ-a, snimila ). Zagora, 2013.)

Angelo Mancini, The Immaculate Virgin, 1609, detail of the back of the canvas with a dark-brown underpainting / coloured preparation (the mixture penetrated to the back of the painting in the stretcher area), Sibenik, church of St. Domenica in the Crnica area (Croatian Conservation Institute Photo Archive, photo by J. Zagora, 2013)

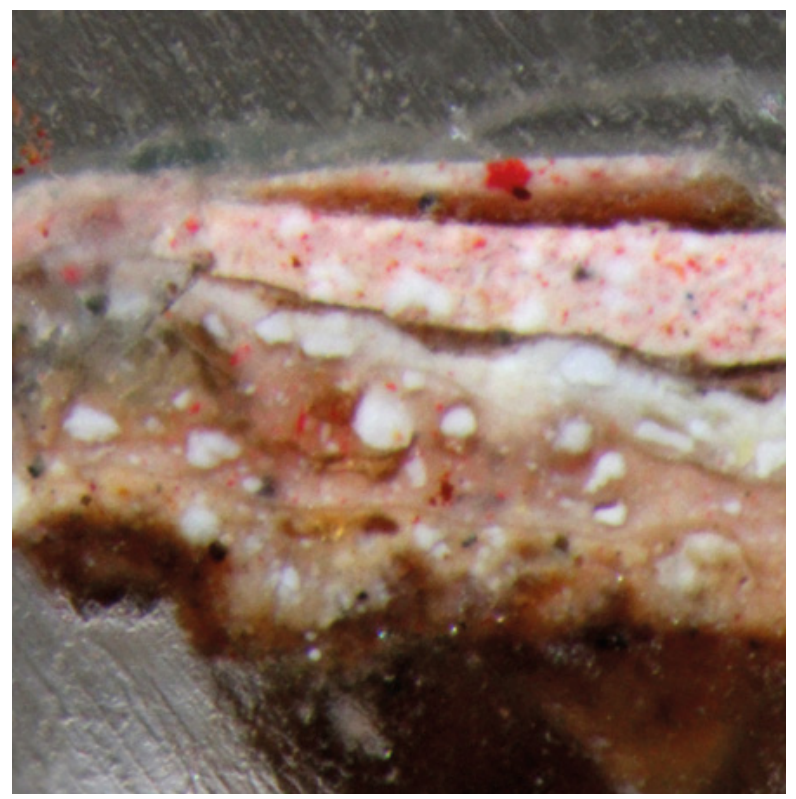

15. Angelo Mancini, Bogorodica Bezgrešna, 1609., mikropresjek slikanog sloja s tamnosmeđim podslikom/obojenom preparacijom (uzorak pozadine desno od anđela /treći odozgo/ u desnom dijelu slike), Šibenik, crkva sv. Nediljice na predjelu Crnica (fototeka HRZ-a, snimila J. Zagora, 2013.)

Angelo Mancini, The Immaculate Virgin, 1609, microsection of the painted layer with a dark-brown underpainting / coloured preparation (sample of the ground to the right of an angel (third from the top) on the right side of the painting), Šibenik, church of St. Domenica in the Crnica area (Croatian Conservation Institute Photo Archive, photo by J. Zagora, 2013)

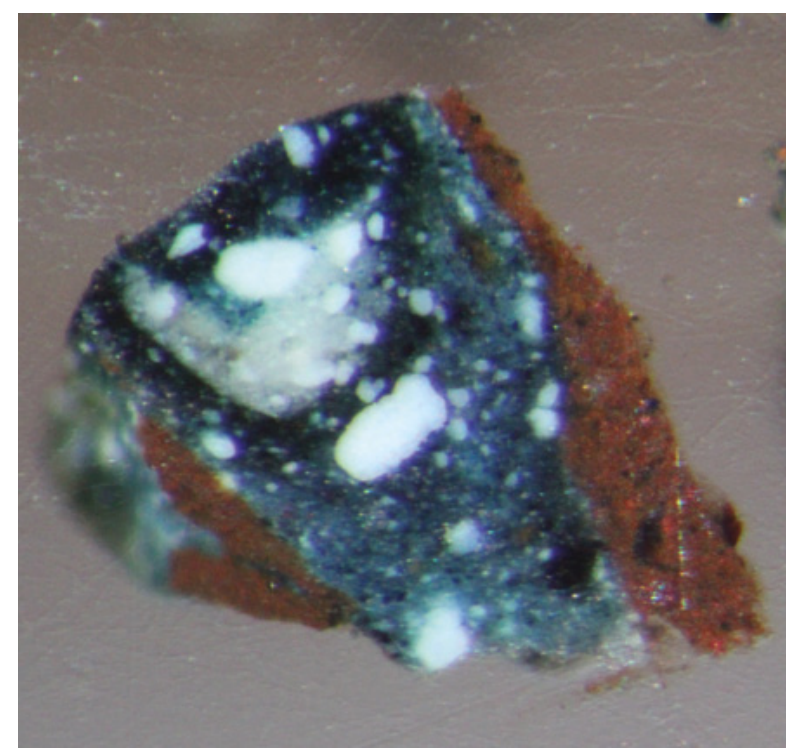

14. Angelo Mancini, Bogorodica Bezgrešna, 1609., mikropresjek smjese boje i tamnosmeđeg podslika/obojene preparacije (uzorak granule s poleđine platna), Šibenik, crkva sv. Nediljice na predjelu Crnica (fototeka HRZ-a, snimila J. Zagora, 2013.)

Angelo Mancini, The Immaculate Virgin, 1609, microsection of the mixture of paint and the dark-brown underpainting / coloured preparation (sample of a granule from the back of the painting), Sibenik, church of St. Domenica in the Crnica area (Croatian Conservation Institute Photo Archive, photo by J. Zagora, 2013)

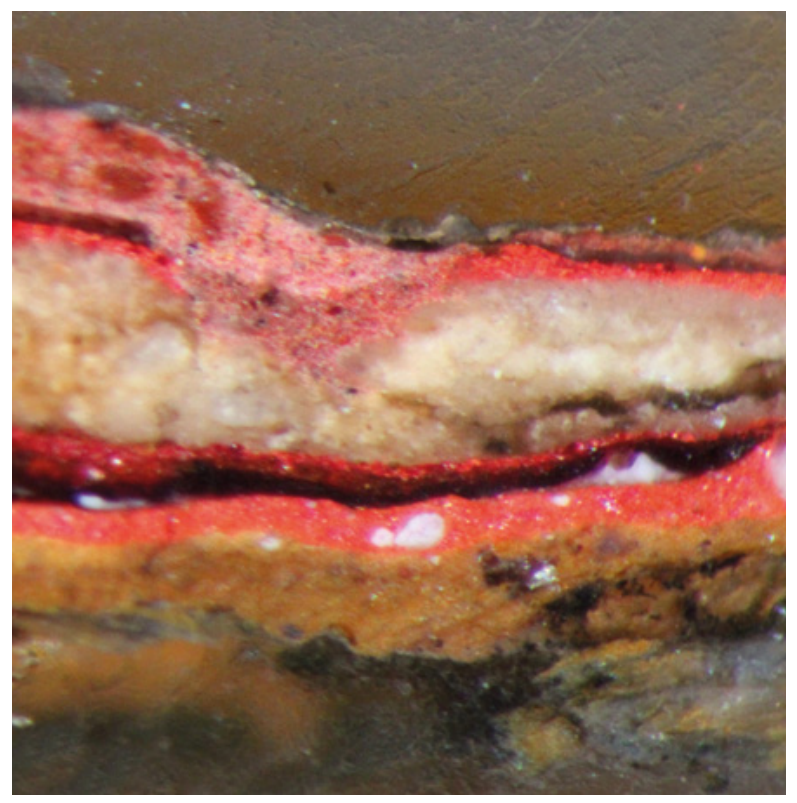

16. Angelo Mancini, Bogorodica Bezgrešna, 1609., mikropresjek slikanog sloja s oker podslikom/obojenom preparacijom (uzorak lijevog dijela Gospina plašta), Šibenik, crkva sv. Nediljice na predjelu Crnica (fototeka HRZ-a, snimila J. Zagora, 2013.) Angelo Mancini, The Immaculate Virgin, 1609, microsection of the painted layer with an ochre underpainting / coloured preparation (sample of the left part of the Virgin's mantle), Šibenik, church of St. Domenica in the Crnica area (Croatian Conservation Institute Photo Archive, photo by J. Zagora, 2013) 
$\mathrm{u}$ navedenim su primjerima velike; $\mathrm{u}$ tom je kontekstu zanimljiv opisani razvoj Canalettovih dvostrukih preparacija koje su nastale iz blokova podslika.

Brojni talijanski i flamanski slikari 16. i 17. stoljeća slike su započinjali nanošenjem "smeđih sjena" unutar iscrtanih kontura, ${ }^{100}$ no koliko sam do sada uspjela istražiti, među europskim slikama na platnu iz 16., 17. i 18. stoljeća nije zabilježen primjer podslika izvedenog izravno na (impregniranom) platnu, bez jednoliko nanesenog sloja osnove. ${ }^{101}$ Iako tema zahtijeva više pažnje, za sada pored slike Bogorodica Bezgrešna iz šibenske crkve sv. Nediljice nisam naišla na sličan primjer uljene slike na platnu s podslikom umjesto jednog uniformnog sloja preparacije ili više njih. Merrifield, zanimljivo, navodi slike Callota, Leonarda da Vincija ili učenika te Andree Pozza koje su, navodno, naslikane izravno na platnu impregniranom tutkalom. ${ }^{102}$ Ipak, slikanje na nosiocu bez preparacije spominje se tek u priručnicima iz 19. stoljeća. ${ }^{103}$ Premda se podslik smatra dijelom slikanog prikaza i stoga ne pripada preparaciji, Mancinijeva Bogorodica Bezgrešna iz Šibenika odstupa od pravila i dokazuje da definiranje stratigrafije slikarskih podloga ne mora uvijek biti jednostavno i jednoznačno. Preparacija i podslik mogu se pretapati u konceptu, funkciji i tehnologiji izvedbe, što potvrđuju i drugi navedeni primjeri. Svakako je to zanimljiva polazna točka za daljnje istraživanje i raspravu o terminologiji.

\section{Zaključak}

Mnogi su slikari, kako primjećuje Nico van Hout, mijenjali boju preparacije ovisno o temi, raspoloženju ili tehnici slikanja, stoga podjela između slika na svijetlim i slika na tamnim podlogama ostaje prilično subjektivna i umjetna. ${ }^{104}$ Doista, nema potpuno čvrste granice između tipova preparacija određenih razdoblja, provenijencija, pa čak ni unutar opusa pojedinih autora - zamjećuje se istovremeno trajanje starih metoda prepariranja, katkad u izmijenjenim oblicima, odnosno postupno, heterogeno usvajanje novih trendova. Prema dosadašnjim istraživanjima, obojene podloge pojavljuju se u sjevernoj Italiji već u drugoj polovici 15. stoljeća: gesso s dodatkom crvenih pigmenata, lokalne i crvene imprimature te one varirajuće boje s obilježjima podslika. Pribrojimo li preparacijama u talijanskom uljenom slikarstvu 16. i 17. stoljeća i opisane dalmatinske, dobivamo cijeli spektar tipova i sastava. Preparacije od gessa s imprimaturom na drvu i na platnu polako prepuštaju mjesto obojenim preparacijama za platneni nosilac, isprva na tankom sloju gessa. Premda se koriste svijetle i tamne obojene preparacije na bazi gipsa, krede i olovne bijele, smeđe preparacije sastavljene pretežito od zemljanih pigmenata postupno prevladavaju u 17. stoljeću. U Dalmaciji je zabilježen primjer s podslikom zemljanih tonova nanesenim izravno na (impregnirano) platno - neuobičajena tehnologija izrade možda je izolirani slučaj, a možda je svojstvena slikaru ili određenom krugu; to tek treba ispitati. Razdoblje prelaska sa svijetlih na tamne imprimature, odnosno tamne obojene preparacije za platno, dobro je istraženo, no crvene preparacije, toliko česte na talijanskim slikama iz 18. stoljeća, ali i na djelima iz drugih europskih zemalja, nisu bile predmet pomnijih analitičkih studija. Iako postoje indicije da se i taj tip preparacija razvio na sjeveru Italije, njihovo porijeklo još uvijek je nerazjašnjeno, kao i vrijeme pojave, odnosno nestanka. Pitanje veziva obojenih preparacija iz 17. i 18. stoljeća na bazi zemljanih pigmenata zahtijeva više pažnje, kao i pojava sjevernoeuropskih dvostrukih preparacija na djelima talijanskih slikara. Tko zna, možda su se upravo zbog nalazišta raznovrsnih zemljanih pigmenata $u$ porječju rijeka Po i Adige smeđe i crvene preparacije najprije pojavile na sjeveru Italije, $u$ regiji $u$ kojoj je gradnja od opeka bila uobičajena. Činjenica je, kako zaključuju Diego Cauzzi i Claudio Seccaroni, da se potraga za obojenim preparacijama i ekspresivnim potencijalom uljenog slikarstva istovremeno događa u više središta - različite osobnosti i slikarske škole eksperimentiraju i razvijaju nove metode neovisno i u interakciji s drugima, posebice u dolini rijeke Po koja je nekad bila važna komunikacijska arterija. ${ }^{105}$ Izvjesno je da će se spoznaje mijenjati i dopunjavati novim istraživanjima slikarskih preparacija i zemljanih pigmenata.

\section{Bilješke}

1 SIGO SUMMERECKER, 1973., 12, 100.

2 Usp. SIGO SUMMERECKER, 1973., 13, 97, 143 (osnove, preparacije - $u$ širem i u užem smislu; za obojene/tonirane osnove koristi i izraz guaš osnove); VIŠNJA BRALIĆ, PAVAO LEROTIĆ, 2004., 151 (preparacija u užem smislu); PAVAO LEROTIĆ, TEA ZUBIN FERRI, 2013., 157 (preparacija - gesso, imprimatura); VIŠNJA BRALIĆ, PAVAO LEROTIĆ, 2008., 79 (osnova - gesso, imprimatura). Ponekad se stječe dojam da se impregnacija (tutkaljenje) promatra kao zasebna faza obrade nosioca i stoga se ne smatra dijelom stratigrafije preparacije. Vidi npr. SIGO SUMMERECKER, 1973., 12, 80.

3 JILL DUNKERTON, MARIKA SPRING, 1998., 120-121.

4 Premda je riječ o dugotrajnoj, općeprihvaćenoj tradiciji u Italiji (vidi npr. STEFANO MARCONI, 1993., 11-12, 28), mlađi autori ne slažu se s takvim korištenjem izraza mestica jer izvorno označava mješavinu boja; oni preferiraju naziv imprimitura. ANGELA CERASUOLO, 2017., 242. Cauzzi i Seccaroni predlažu da se značenje imprimiture ograniči na homogenu izolaciju gessa na 
slikama na drvu ili na uljenu preparaciju na platnu (koje može biti samo impregnirano, a može imati još i osnovu koja nije vezana uljem, a služi za poravnavanje teksture tkanja). DIEGO CAUZZI, CLAUDIO SECCARONI, 2007., 106. Ipak, obojene preparacije 17. i 18. stoljeća ne moraju biti uljene, što se u praksi često primjećuje (bilješka 69). Kao i značenje naziva priming, značenje termina imprimitura u novijim je tekstovima kadkad nejasno, budući da nije uvijek naznačeno je li riječ o sloju nanesenom na gesso ili izravno na nosioca. Osim toga, u tekstovima suvremenih autora koji pišu na talijanskom i engleskom jeziku (navedenih u ovome radu) može se primijetiti prilično nedosljedno navođenje varijanti imprimatura, odnosno imprimitura - na temelju istih izdanja tekstova Vasarija i Baldinuccija, citiraju se različite inačice izraza, stoga pitanje koja je varijanta starija zahtijeva zasebno bibliografsko istraživanje. Navest ću, ipak, recentni doprinos Angele Cerasuolo. Prema njezinim navodima, izrazom imprimatura Leonardo da Vinci (oko 1490. - 1495.) i Armenini (1586.) označavaju sloj preparacije od ulja i pigmenata, dok Vasari (izdanja iz 1550. i 1568.) sinonimno upotrebljava i naziv mestica, kao i Baldinucci, koji u 17. stoljeću navodi inačicu imprimitura. Čini se da i tu varijantu prvi spominje Leonardo (neka kasnija izdanja njegovoga traktata bilježe samo tu inačicu). ANGELA CERASUOLO, 2017., 190, 194, 238-242; LEONARDO DA VINCI, 1890., 168; GIORGIO VASARI, 1568., 52-53; FILIPPO BALDINUCCI, 1681. Svakako, u domaćoj se praksi uobičajila varijanta imprimatura, koju ću u ovome radu definirati i upotrebljavati u povijesno i tehnološki ograničenom značenju, kako je uglavnom uobičajeno među suvremenim netalijanskim autorima.

5 MAARTJE STOLS-WITLOX, 2014., 67-70.

6 MAARTJE STOLS-WITLOX, 2014., 72-73. Primjerice, punilo u tradicionalnom gessu je gips, dok su u tamnim baroknim preparacijama to zemljani pigmenti; u oba slučaja punilo daje masu, no uvelike određuje i boju koja se može modificirati dodatkom drugih pigmenata. U cilju izbjegavanja pogrešne interpretacije, nazive „punilo“ i „pigment“ prenosim doslovno, kako ih navode autori tekstova.

7 Preparacije sa slojem gessa na platnu i debelim slojem obojene podloge pojavljuju se u ranom 16. stoljeću tijekom prelaska s imprimatura na obojene preparacije. Sloj gessa često je vrlo tanak i jedva da popunjava tkanje platna pa je njegova primarna funkcija reguliranje apsorpcije veziva. ANGELA CERASUOLO, 2017., 240. lako gesso ne čini osnovu takvih preparacija, po uzoru na inozemne publikacije ipak ću zadržati taj naziv. Obojeni sloj u takvim se slučajevima ne može definirati kao imprimatura, budući da ima uloge osnove i obojene podloge za slikanje, a možda i izolacije (na njega može biti nanesena i nepigmentirana izolacija, no ne nužno). Takav tip preparacija može se stoga nazvati obojenim preparacijama, uz napomenu da je na platno najprije nanesen (tanki) sloj gessa.

8 DIEGO CAUZZI, CLAUDIO SECCARONI, 2007., 104. Cauzzi i Seccaroni ne preciziraju je li povrh pigmentiranog gessa nanesena i izolacija, stoga pigmentirani gesso ovdje neću definirati kao osnovu, nego kao preparaciju. lako pigmentirani gesso prema tipologiji pripada obojenim preparacijama, zbog povijesne speci- fičnosti i samo nekoliko poznatih primjera, izdvojila sam ga kao posebnu kategoriju gesso preparacije.

9 NICO VAN HOUT, 1998., 199-200.

10 MAARTJE STOLS-WITLOX, 2012., 161.

11 Kod nas se koriste izrazi „obojena“ i „tonirana“, no prvi je možda prikladniji, budući da bolje odražava kromatičnost i činjenicu da su preparacije koje se uvode u 16. stoljeću i dominiraju u sljedeća dva stoljeća sastavljene pretežito od zemljanih pigmenata koji zato imaju i ulogu punila. $U$ engleskom jeziku također je uobičajen termin coloured ground/preparation.

12 Može biti riječ o završnom sloju bilo kojeg tipa preparacije objašnjenog u ovome tekstu - imprimaturi, njezinim varijantama ili varijantama obojene preparacije, odnosno gornjem sloju dvostruke preparacije, neovisno o tome ima li još i nepigmentiranu izolaciju.

13 MAARTJE STOLS-WITLOX, 2012., 166.

14 JILL DUNKERTON, MARIKA SPRING, 1998., 121. Kao i platneni nosilac, uljano slikarstvo u Italiji se uvodi u 15. stoljeću (postupno zamjenjuje jajčanu temperu u razdoblju renesanse, no mješoviti sustavi veziva dugo ostaju u upotrebi). JILL DUNKERTON, ASHOK ROY, 1998., 26-30; ERMA HERMENS, JOYCE TOWNSEND, 2012., 208-209. Slikanje na platnu u Veneciji često se povezuje s razvijenom tekstilnom industrijom (naročito izradom jedara) i olakšavanjem transporta, što spominje još i Vasari - platno se može zarolati, a zbog kanala u Veneciji plovila i teret trebaju biti lagani. MAARTJE STOLS-WITLOX, 2014., 86. 15 Premda vezivo, tehnika slikanja i metode prepariranja malobrojnih sačuvanih talijanskih i sjevernoeuropskih primjera slikarstva na platnu iz 15. stoljeća znatno variraju, platno slika izrađenih u vodenom vezivu često je samo impregnirano tutkalom, katkad s dodatkom punila (kreda, gips). Cennini opisuje preparaciju od tankog sloja gessa za popunjavanje međuprostora između niti uz dodatak štirke ili šećera za povećanje fleksibilnosti. Gesso na platnu mora biti tanak zbog opasnosti od raspucavanja i osipanja slikanog sloja, kako je o praksi svojih prethodnika zapisao Volpato u 17. stoljeću. lako Vasari ne preporučuje gesso ako slike treba zarolati jer može otpasti, nije dokazano da je to razlog za uvođenje obojenih preparacija u uljenom vezivu - možda zbog postupnog napuštanja prakse pozlaćivanja slika, preparacije slika na drvu se u 15. i 16. stoljeću također pojednostavnjuju, postaju manje pažljivo nanesene, manje zaglađene i tanje. U Italiji se napuštaju elaborirane dvoslojne gesso preparacije (gesso grosso i gesso sottile, kako Cennini naziva kalcijev sulfat anhidrit i kalcijev sulfat dihidrat), a kredne preparacije na sjeveru postaju tako tanke da se nazire struktura nosioca (zbog kvalitetnijeg drva, na sjeveru su preparacije i u 15. stoljeću tanje od talijanskih i rjeđe se prekrivaju platnom prije prepariranja). JILL DUNKERTON, ASHOK ROY, 1998., 26, 30; MAARTJE STOLS-WITLOX, 2012., 166-167; CENNINO CENNINI, 2007., 98-104, 134-135; MAARTJE STOLS-WITLOX, 2014., 80-85, 87-88, 100; JILL DUNKERTON, SUSAN FOISTER, NICHOLAS PENNY, 1999., 217-222, 271.

16 Tutkalni, uljni i uljno-smolni nepigmentirani izolacijski slojevi pojavljuju se u Italiji od 14. do 16. stoljeća. Prelaskom na uljeno 
slikarstvo tijekom 15. stoljeća postaju sve važniji. lako je općenito prihvaćen stav da su obojene izolacije (imprimature) prije uvedene u Italiji nego na sjeveru Europe, neki autori smatraju da je to teško dokazati na temelju dosadašnjih istraživanja. Neki flamanski i njemački umjetnici upotrebljavali su svijetle pigmentirane imprimature od olovne bijele na drvu (braća Van Eyck, Rogier Van der Weyden), no primjeri snažnije obojenih podloga prema dosadašnjim se istraživanjima ondje pojavljuju u kasnom 15. i tijekom prve polovice 16. stoljeća. MAARTJE STOLS-WITLOX, 2012., 164-166; DIEGO CAUZZI, CLAUDIO SECCARONI, 2007., 101-102; MAARTJE STOLS-WITLOX, 2014., 89.

17 MAARTJE STOLS-WITLOX, 2012., 165-166. U kontekstu uljenog slikarstva spominje ih Averlino Filarete 1463. godine, opisujući imprimaturu od lanenog ulja i olovne bijele $u$ koju se može dodati i bilo koja druga boja. DIEGO CAUZZI, CLAUDIO SECCARONI, 2007., 99.

18 Citirajući Vasarija i Filaretea, Stols-Witlox tvrdi da su obojene podloge u talijanskom slikarstvu na platnu uvedene potkraj 15. stoljeća. Zanimljivo, u sjeverozapadnoj Europi, gdje su snažno pigmentirane imprimature i obojene preparacije uvedene kasnije nego $u$ Italiji, obojene podloge uvedene su znatno ranije $u$ vodenom slikarstvu na platnu. Tako je u tutkalnoj impregnaciji platna Dierica Boutsa utvrđen smeđi oker (Polaganje u grob, 1450. 1460., Nacionalna galerija, London). MAARTJE STOLS-WITLOX, 2012., 165-166; MAARTJE STOLS-WITLOX, 2014., 85-86. Pigmentirane tutkalne preparacije zabilježene su i na češkim i slovačkim slikama na platnu iz 15. stoljeća. JANKA HRADILOVÁ, DAVID HRADIL, 2014., 116-119.

19 DIEGO CAUZZI, CLAUDIO SECCARONI, 2007., 91-111. Srdačno zahvaljujem Claudiju Seccaroniju (ENEA - Agenzia nazionale per le nuove tecnologie, l'energia e lo sviluppo economico sostenibile) na poslanoj publikaciji; premda je izuzetno važna, nedovoljno je poznata (studija je objavljena u izložbenom katalogu). Prema temeljnom istraživanju jill Dunkerton i Marike Spring, smatralo se da su se obojene podloge pojavile u drugom desetljeću 16. stoljeća. JILL DUNKERTON, MARIKA SPRING, 1998., 120-130.

20 DIEGO CAUZZI, CLAUDIO SECCARONI, 2007., 104-105. Zanimljivo, Merrifield iznosi da su Giovanni Bellini (Gian Bellino) i drugi (?) u gesso katkad dodavali malo crnog pigmenta. MARY PHILADELPHIA MERRIFIELD, 1849., cclxxxviii. U svjetlu tih pronalazaka, Cauzzi i Seccaroni smatraju da zesso beretin (sivi gesso) iz popisa inventara Palme starijeg, koji Dunkerton i Spring interpretiraju kao gesso sa sivom imprimaturom, može biti i gesso $\mathrm{s}$ dodatkom crnog pigmenta. Preparacije s punilom od gipsa $\mathrm{i}$ dodatkom pigmenata zabilježene su i u 16 . stoljeću, no nije poznato vezivo. Zanimljiv je i pronalazak gessa s dodatkom ugljene crne na drvenoj polikromiranoj skulpturi sv. Petra iz šibenske katedrale (datirana u 15. stoljeće). Temu istražuje Anna Košar u sklopu diplomskog rada (Državna akademija likovnih umjetnosti u Stuttgartu). U ovom je kontekstu zanimljivo da Cennini za izradu reljefnih ukrasa spominje gesso sottile pigmentiran armenskim bolusom. CENNINO CENNINI, 2007., 103. Na sjeveru je neuobičajen pronalazak žutog okera u krednoj preparaciji oltara
Revaler (Tallinn) radionice Bernta Notkea (djelatan u baltičkoj regiji) iz 1483. godine. MAARTJE STOLS-WITLOX, 2012., 164. 21 DIEGO CAUZZI, CLAUDIO SECCARONI, 2007., 101-102, 106. 22 ANDREA KIRSH, RUSTIN S. LEVENSON, 2000., 76.

23 Vezivo boje i spomenutih slojeva varira od jaja i ulja do tutkala, iako je analizirano vrlo malo primjera. DIEGO CAUZZI, CLAUDIO SECCARONI, 2007., 101, 102.

24 Mjestimično nanesene pigmentirane slojeve utvrđene ispod nekih dijelova oslika jill Dunkerton i Marika Spring opisuju kao local priming, što se može prevesti kao lokalna imprimatura. JILL DUNKERTON, MARIKA SPRING, 1998., 122; LORENZO LAZZARINI, 1983., 138; DIEGO CAUZZI, CLAUDIO SECCARONI, 2007., 102; ANDREA ROTHE, DAWSON W. CARR, 1998., 60.

25 JILL DUNKERTON, MARIKA SPRING, 1998., 122; DIEGO CAUZZI, CLAUDIO SECCARONI, 2007., 102-104; LORENZO LAZZARINI, 1983., 135-140; NICO VAN HOUT, 1998., 215, 223; PAVAO LEROTIĆ, VIŠNJA BRALIĆ, 2008., 77-90.

26 Sivo-smeđu imprimaturu ostavlja vidljivom na pozadinama prizora, a tamne boje nanosi u tankom sloju. JILL DUNKERTON, MARIKA SPRING, 1998., 122-123; DIEGO CAUZZI, CLAUDIO SECCARONI, 2007., 102-103; BARBARA H. BERRIE, 1994., 307-313.

27 DIEGO CAUZZI, CLAUDIO SECCARONI, 2007., 104.

28 Neke načine impregniranja (tutkaljenja) i prepariranja platna u slikarskim traktatima bilježe Giorgio Vasari i Giovanni Battista Armenini. MAARTJE STOLS-WITLOX, 2012., 167; JILL DUNKERTON, SUSAN FOISTER, NICHOLAS PENNY, 1999., 271.

29 NICO VAN HOUT, 1998., 213; JILL DUNKERTON, SUSAN FOISTER, NICHOLAS PENNY, 1999., 271; LORENZO LAZZARINI, 1983., 138, 140.

30 MAARTJE STOLS-WITLOX, 2014., 79-80, 89. Recepture za platno čine se nešto tamnije boje od onih za drvo, no u rukopisima se ne raspravlja o tim razlikama. Van de Wetering smatra da je to zbog različitog porijekla nosioca - na slikarstvo na drvu utjecala je sjevernoeuropska tradicija, dok su tehnike slikanja na platnu potekle iz Italije. ERNST VAN DE WETERING, 1997., 129. 31 Eksperimentirao je is debelom crveno-smeđom preparacijom na gessu te svjetlijim obojenim preparacijama. JILL DUNKERTON, MARIKA SPRING, 1998., 121-122. Autorice drže da je vezivo istraženih imprimatura i obojenih preparacija sušivo ulje, navodeći da je u nekoliko slučajeva provedena zasebna analiza veziva. 32 JILL DUNKERTON, SUSAN FOISTER, NICHOLAS PENNY, 1999., 272. Slike su izrađene na tutkaljenom platnu tako da su na sivoj pozadini srednjeg tona modelirani svjetlosni akcenti $i$ sjene. Neke od Mantegninih slika toga tipa čuvaju se i u Nacionalnoj galeriji u Londonu.

33 JILL DUNKERTON, MARIKA SPRING, 1998., 122.

34 DIEGO CAUZZI, ANDREA G. DE MARCHI, PIETRO MOIO-

LI, CLAUDIO SECCARONI, 2012., 26-37.

35 DIEGO CAUZZI, CLAUDIO SECCARONI, 2007., 91.

36 JILL DUNKERTON, MARIKA SPRING, 1998., 123, 129; DAVID HRADIL et al., 2011.

37 JILL DUNKERTON, SUSAN FOISTER, NICHOLAS PENNY, 1999., 271; MAARTJE STOLS-WITLOX, 2012., 168. 
38 JILL DUNKERTON, MARIKA SPRING et al., 2013., 16, 82. 39 JILL DUNKERTON, MARIKA SPRING, 1998., 123; JILL DUNKERTON, SUSAN FOISTER, NICHOLAS PENNY, 1999., 271.

40 Tanki sloj bijele boje utisnut u tkanje vjerojatno se sastoji od gipsa. Arhiv Hrvatskog restauratorskog zavoda, DOMACOJ MUDRONJA, MIRJANA JELINČIĆ, MARGARETA KLOFUTAR, Laboratorijska izvješća br. 253/2015 i 278/2015, Zagreb, 2015. Zahvaljujem Radoslavu Tomiću na informacijama o atribuciji i dataciji. Slika se restaurira od 2015. godine pod vodstvom Zrinke Lujić (HRZ, Restauratorski odjel u Splitu). Autorica ovoga rada bila je suradnica na programu. Zahvaljujem kolegici Lujić na fotografijama.

41 DAVID HRADIL et al, 2011; MAARTJE STOLS-WITLOX, 2014., 87; JILL DUNKERTON, MARIKA SPRING, 1998., 127.

42 MARY PHILADELPHIA MERRIFIELD, 1849., cclxxxv, cclxxxvii, 730-732, 772; ZAHIRA VELIZ, 1982., 51. lako recepte za impregniranje platna pastom od brašna spominju razni slikarski priručnici u Europi iz 17. i 18. stoljeća, takva smjesa još uvijek nije utvrđena na suvremenim slikama. MAARTJE STOLS-WITLOX, 2012., 173. 43 ALAIN R. DUVAL, 1994., 38; MAARTJE STOLS-WITLOX, 2012., 173; ASHOK ROY, 1999.b, 59, 82.

44 HELEN GLANVILLE, 1995., 15; MARGARET BARKOVIC, MARGARET SHEEHAN, 2015., 37. U prilog tezi o venecijanskom porijeklu preparacija s kredom, autorica navodi samo Tizianovu Bogorodicu s Djetetom (oko 1525.). Smatra da nije provedeno dovoljno analiza za utvrđivanje sastava veziva takvih preparacija. 45 ELISABETH MARTIN, 2008., 59-67. Autorica napominje da treba dalje analitički ispitivati razlike sijene i umbre, a na samo jednom mjestu definira boju kao žuto-smeđu. Čini se da zbog dodatka sikativnih pigmenata podrazumijeva da je riječ o uljenom vezivu, iako u samo jednom slučaju navodi analitičku potvrdu ulja. 46 MOJMÍR HAMSÍK, 1993.

47 VIŠNJA BRALIĆ, PAVAO LEROTIĆ, 2004., 150, 151. Potkraj 16. stoljeća slikao je na preparaciji od gessa, a koristio se i žuto-smeđom uljenom preparacijom na bazi olovne bijele. ELISABETH MARTIN, 2008., 65; NICHOLAS PENNY, MARIKA SPRING, 1995., 25.

48 FRANCESCA CAPANNA, ANNA MARIA MARCONE, FRANCESCA ROMANA SINAGRA, 2012., 17-164; FRANCESCA CAPANNA, GIULIA CERVI, FRANCESCA DAL MASCHIO, MARIA ENRICA GIRALICO, FRANCESCA MANCINELLI, MIRIAM PITOCCO, 2006., 59-62. Srdačno zahvaljujem dr. Franceski Capanni na ustupljenim publikacijama. Autori kataloga uglavnom pretpostavljaju da je riječ o uljenim preparacijama, no bez analitičkih potvrda.

49 MAARTJE STOLS-WITLOX, 2014., 87, 203-208.

50 MAARTJE STOLS-WITLOX, 2012., 173, prema ASHOK ROY, 1999.b, 59. lako je mogućnost bolonjskog porijekla crvenih preparacija vrlo zanimljiva, referenca je upitna - autorica ne iznosi ni jedan primjer crvene preparacije, a Roy na navedenoj stranici uopće ne spominje crvene, već svijetlosmeđe preparacije. Od Stols-Witlox, na žalost, nisam dobila odgovor.

51 MAARTJE STOLS-WITLOX, 2012., 173; NICO VAN HOUT, 1998., 215-216; MAARTJE STOLS-WITLOX, 2012., 173; ELISABETH MARTIN, 2008., 63; ALAIN R. DUVAL, 1994., 35-41.
52 Pretpostavlja se da je putovao Italijom i radio u Tintorettovoj radionici. NICO VAN HOUT, 1998., 224.

53 Pridjev la rossa Bologna ponajviše duguje povijesnim zgradama od crvenih opeka (poslije su tome pridodane i političke konotacije). SHARON LA BODA, 1994., 96. Zahvaljujem prof. Maji Milanović na referenci.

54 MARY PHILADELPHIA MERRIFIELD, 1849., cxlvii, cclxxxix. 55 Symonds je tada živio u Italiji. KARIN GROEN, 2005.a, 142; MARGARET BARKOVIC, MARGARET SHEEHAN, 2015., 37. Canini se u Rimu obučavao u radionici Bolonjca Domenichina. HELEN GLANVILLE, 1995., 14.

56 MARY PHILADELPHIA MERRIFIELD, 1849., cCxcii.

57 Dunkerton i Spring u studiju preparacija slika iz 16. stoljeća nisu uključile rana djela Carraccijevih iz londonske Nacionalne galerije jer su iz ranog 17. stoljeća, a navode i da Galerija ima malo djela iz 1580-ih i 1590-ih godina. JILL DUNKERTON, MARIKA SPRING, 1998., 120. Akademija Carracijevih (osnovana 1586.) smatra se ključnom za razvoj talijanskog slikarstva 17. stoljeća, a Palma mlađi surađivao je u produkciji prvih praktičnih crtačkih priručnika tiskanih u Italiji, i to u Veneciji (1608. i 1611. godine), iako se temelje na slikarskoj tradiciji središnje Italije, posebice akademije Carraccijevih. DAVID ROSAND, 1970., 5; HELEN GLANVILLE, 1995., 12.

58 MARY PHILADELPHIA MERRIFIELD, 1849., clxx.

59 LORENZO LAZZARINI, 1983., 136.

60 NICHOLAS EASTAUGH, VALENTINE WALSH, TRACEY CHAPLIN, RUTH SIDDAL, 207, 208, 366, 389.

61 KATE HELWIG, 2007., 44-45.

62 Zbog velike količine potrebne za prekrivanje površine slika, zemljani pigmenti namijenjeni izradi slikarskih preparacija morali su biti dostupni i jeftini, stoga su često nabavljani lokalno. Povijesni slikarski traktati bilježe lokalne izvore gline i drugih zemljanih pigmenata. ZAHIRA VELIZ, 1982., 51; MARÍA DOLORES GAYO, MAITE JOVER DE CELIS, 2010., 7-8, 18; KARIN GROEN, 2011., 320; KATE HELWIG, 2007., 51. Slikari su rabili materijale i sirovine namijenjene lončarskoj, zvonarskoj ili opekarskoj industriji ili njima srodnim industrijama, dok na putovanjima ili nakon preseljenja usvajaju lokalnu praksu. Akumulirani analitički podaci iz prijašnjih istraživanja te novije studije diljem Europe iznose puno dokaza tome u prilog, osobito za 17. stoljeće. Zbog doprinosa utvrđivanju provenijencije slika, geološko porijeklo zemljanih pigmenata u preparacijama sve se više istražuje. Vidi npr. BARBARA H. BERRIE, 1994., 307-313; JO KIRBY, 1999., 5-49, 28, 29; TOMÁŠ GRYGAR, JANKA HRADILOVÁ, DAVID HRADIL, PETR BEZDIČKA, SNEJANA BAKARDIJEVA, 2003., 1154-1160; CARLO LALLI, 2009., 24-27; DAVID HRADIL et al., 2011; DAVID HRADIL, JANKA HRADILOVÁ, PETR BEZDIČKA, SILVIE ŠVARCOVA, 2015., 17.

63 MARY PHILADELPHIA MERRIFIELD, 1849., 721-724, 730, 732; STEFANO MARCONI, 1993., 32.

64 STEFANO MARCONI, 1993., 33; PHILIP HENDY, ARTHUR S. LUCAS, JOYCE PLESTERS, 1968., 257-265.

65 MOJMÍR HAMSÍK, 1993. 
66 Kao naziv koji je sam po sebi razumljiv, izraz traditional Venetian red ground navodi se, primjerice, u kontekstu Canalettovih crvenih preparacija. VIOLA PEMBERTON-PIGOTT, 1989., 63. 67 ALAIN R. DUVAL, 1992., 239-258. Duval zemljane pigmente klasificira u tri skupine: smeđe feruginozne zemlje siromašne željeznim oksidima, a bogate silikatnim mineralima (udio $\mathrm{Fe}<$ $10 \%)$, crvene i žute okere ( $\mathrm{Fe}<60 \%)$ te relativno čiste željezne okside (Fe $>60 \%$ ). Kad preparaciju čini jedan obojeni pigment, to je uvijek oker; boja preparacija na bazi kalcijeva karbonata najčešće je postignuta dodavanjem manje količine čistih željeznih oksida velike snage bojenja. Barit do tada nije utvrđen na slikama nastalim prije 1780-ih godina, a vjerojatno ga je dodavao neki pariški dobavljač kao punilo. Zbog indeksa refrakcije sličnog uljenom vezivu i velike težine, barit je pogodan za trgovačke prijevare; za izradu preparacija potrebna je velika količina punila i pigmenata, stoga je vjerojatno u prodaji bila posebna mješavina (u slojevima boje barit nije utvrđen). ALAIN R. DUVAL, 1992., 254-257. $68 U$ praksi sam se susrela s takvim preparacijama, primjerice na slikama Filippa Naldija (Bogorodica sa svecima, 18. stoljeće, župna crkva sv. Jurja, Baćina; Cospa od Ružarija sa sv. Jeronimom i sv. Rokom i Gospa od Karmela i krštenje Krista, 1761., župna crkva sv. Mihovila, Kostanje) i na slici Sv. Ivan evanđelist Antonija Molinarija (crkva Sv. Križa, Čiovo). Arhiv Hrvatskog restauratorskog zavoda, DOMAGOJ MUDRONJA, MIRJANA JELINČIĆ, Laboratorijsko izvješće br. 191/2013., Zagreb, 2013.; DOMAGOJ MUDRONJA, MIRJANA JELINČIĆ, Laboratorijsko izvješće br. 2193/1 (2012.), Zagreb, 2012.; DOMAGOJ MUDRONJA, LEA SOVIĆ, MIRJANA JELINČIĆ, Laboratorijsko izvješće br. 110/2015, Zagreb, 2015. Zbog vremena nastanka i tragova elemenata $\mathrm{Si}$, Ti itd., može se isključiti mogućnost sintetskih željeznih oksida, tzv. Mars pigmenata, uvedenih u kasnom 18. stoljeću. Poznato je da se crveni pigment od željeznog oksida (često pod nazivom engleska crvena) u 18. stoljeću proizvodio kalciniranjem francuskog žutog okera u Nizozemskoj. KATE HELWIG, 2007., 65-66, 94.

69 To tvrdim na osnovi vlastitih, ali i iskustava konzervatorarestauratora s dugogodišnjom praksom, među kojima su Jurica Matijević (Umjetnička akademija, Split) i dr. Francesca Capanna (Istituto Superiore per la Conservazione ed il Restauro, Rim). Zahvaljujem kolegama na informacijama i razmjeni mišljenja. Volpato, Lebrun i De Mayerne bilježe i emulzijske preparacije. MARY PHILADELPHIA MERRIFIELD, 1849., 723; MAARTJE STOLS-WITLOX, 2012., 176. Čini se da su dokazane nekim istraživanjima, što sam već navela, no u inozemnoj literaturi za sada nisam pronašla primjere obojenih preparacija na bazi zemljanih pigmenata s isključivo hidrofilnim vezivom, osim u slučaju donjih slojeva sjevernoeuropskih dvostrukih preparacija.

70 Prema mojem bibliografskom istraživanju i osobnoj komunikaciji s kolegama u Splitu i Italiji, istraživanja preparacija objavljena u brojnim doppo il restauro publikacijama talijanski istraživači tek trebaju objediniti (osobna komunikacija s Juricom Matijevićem i Francescom Capannom).

71 Namjera mi je objediniti i analizirati podatke o platnima i preparacijama na umjetninama iz programa Restauratorske radionice u Splitu koji se mogu naći u arhivu Hrvatskog restaura- torskog zavoda i izvješćima Prirodoslovnog laboratorija Hrvatskog restauratorskog zavoda, što sam počela tijekom stažiranja. 72 Stols-Witlox i Marconi u svojim pregledima detaljno opisuju prijelaz na bijele preparacije u Europi 18. stoljeća, no uopće ne dotiču Italiju. MAARTJE STOLS-WITLOX, 2012., 175-185; STEFANO MARCONI, 1993., 33-34.

73 Za obojene preparacije sastavljene od dva sloja različite boje (najčešće s tamnijim donjim slojem) u engleskom je govornom području uobičajen naziv double grounds. Vidi npr. MAARTJE STOLS-WITLOX, 2012., 175. lako je vjerojatno često riječ o preparacijama s dvostrukom osnovom, budući da izraz ground autorica u navedenom radu koristi u generičkom, širem značenju, a uz to oba sloja osnove mogu imati i svoju izolaciju (izolacija donjeg sloja svojevrsna je impregnacija za gornji sloj), u ovome radu upotrebljavam obuhvatniji izraz dvostruke preparacije.

74 Vezano za pojavu dvostrukih preparacija u 16. stoljeću, Stols-Witlox citira neobjavljeni studentski rad Nicole Christie (The grounds of paintings. A comparative survey of the theory and practice of priming supports, from the twelfth to the mid-eighteenth centuries, Hamilton Kerr Institute, Cambridge, 1988.), ali ne navodi podatak o zemlji iz koje slike potječu. Iznosi da se šire iz sjeverne Nizozemske i Flandrije u 17. stoljeću. MAARTJE STOLS-WITLOX, 2012., 168, 175; MAARTJE STOLS-WITLOX, 2014., 93-93. Iz Instituta Hamilton Kerr nisam dobila odgovor. Poklonstvo kraljeva Maartena de Vosa (1599., Musée des BeauxArts, Valenciennes) s crveno-sivom dvostrukom preparacijom najraniji je objavljeni primjer koji sam uspjela pronaći. NICO VAN HOUT, 1998., 215, 224.

75 MAARTJE STOLS-WITLOX, 2012., 175; KARIN GROEN, 2005. b, 83.

76 NICO VAN HOUT, 1998., 224; ASHOK ROY, 1999. a, 89-95; MAARTJE STOLS-WITLOX, 2012., 168, 175-176; KARIN GROEN, 2011., 36-47; MAARTJE STOLS-WITLOX, 2013., 175-176; ANTÓNIO JOÃO CRUZ, CARLA REGO, 2014., 479-492.

77 GROEN, 2011., 35-36; ANN MASSING, 1995., 21; MAARTJE STOLS-WITLOX, 2014., 92.

78 Smolni slojevi pronađeni su na djelima Bouchera, Rubensa i Judith Leyster. ELMA O'DONOGHUE, RAFAEL ROMERO, JORIS DIK, 1998., 186; NICO VAN HOUT, 1998., 224; KARIN GROEN, 2011., 210. Engleske dvostruke preparacije imaju tutkalnu impregnaciju između slojeva. ROXANE SPERBER, JENS STENGER, 2016. Na slici iz šibenske katedrale vezivo također može biti proteinsko, no ne može se isključiti ni mogućnost saharidnog, odnosno emulzijskog veziva (bilješka 88).

79 MOJMÍR HAMSÍK, 1993.

80 MARGARET BARKOVIC, MARGARET SHEEHAN, 2015., 22, 36, 56-62.

81 ELISABETH MARTIN, 2008., 62-63; FRANCESCA CAPANNA, ANNA MARIA MARCONE, FRANCESCA ROMANA SINAGRA, 2012., 18, 33; FRANCESCA CAPANNA, GIULIA CERVI, FRANCESCA DAL MASCHIO, MARIA ENRICA GIRALICO, FRANCESCA MANCINELLI, MIRIAM PITOCCO, 2006., 59-62.

82 MOJMÍR HAMSÍK, 1993.

83 MAARTJE STOLS-WITLOX, 2012., 168, 175-176. 
84 VIOLA PEMBERTON-PIGOTT, 1989., 57, 63; DAVID BOMFORD, ASHOK ROY, 1993., 40. S

85 ROXANE SPERBER, JENS STENGER, 2016.

86 Dokumenti u Veneciji spominju kupnju telle imprimite. ELISE EFFMANN, 2006., 194.

87 Za stilsku dataciju i utvrđivanje provenijencije zaslužan je Radoslav Tomić. JELENA ZAGORA, 2015., 6, 12-16. Slika je restaurirana 2015. godine pod vodstvom Branka Pavazze uz suradnju Jelene Zagore.

88 Aluminij je detektiran u dva uzorka, a silicij u svim uzorcima, no oba tek u tragovima. Arhiv Hrvatskog restauratorskog zavoda, DOMAGOJ MUDRONJA, MIRJANA JELINČIĆ, Laboratorijsko izvješće br. 197/2014, Zagreb, 2014.; DOMAGOJ MUDRONJA, MIRJANA JELINČIĆ, Laboratorijsko izvješće br. 55/2015, Zagreb, 2015. Vezivo nije analizirano; izrazitu osjetljivost donjeg sloja preparacije na vodu zamijetila sam tijekom zahvata.

89 Sliku je prema stilu datirao Radoslav Tomić. Godine 2015. restaurirao ju je Josip Delić (HRZ, Restauratorski odjel u Splitu). Zahvaljujem kolegi Deliću na ustupljenim fotografijama.

90 MAARTJE STOLS-WITLOX, 2012., 175-176; MAARTJE STOLSWITLOX, 2014., 114-127, 213-217; ERNST VAN DE WETERING, 2009., 22.

91 ELMA O'DONOGHUE, RAFAEL ROMERO, JORIS DIK, 1998., 185-187. Vidi i KARIN GROEN, 2011., 320; SIGO SUMMERECKER, 1973., 144.

92 O tome svjedoče pribilješke s margina De Mayerneova traktata. Recepte za izradu dvostrukih preparacija dobio je u Londonu od preparatora iz Wallonije te amsterdamskog slikara Latombéa. KARIN GROEN, 2011., 320, 321. Osim brojnih referenci na komercijalno preparirana platna u dokumentima i priručnicima od 16. do 19. stoljeća (pretežito iz sjeverne Europe), izvori bilježe i dokaze da su slikari u cijelom razdoblju nastavili sami preparirati platna (katkad zbog loših iskustava s kvalitetom komercijalnih preparacija), a katkad su modificirali kupljena preparirana platna. STOLS-WITLOX, 2014., 218-233; MAARTJE STOLS-WITLOX, 2012., 175.

93 KARIN GROEN, 2005.b, 18-27.

94 JELENA ZAGORA, 2016., 251-274. Slika je restaurirana 2013. godine pod vodstvom Žane Matulić Bilač (HRZ, Restauratorski odjel u Splitu) uz suradnju Sandre Šustić, Julije Baćak i Jelene Zagore. JELENA ZAGORA, 2014., 16, 18-21 (neobjavljeno izvješće). U pripremi je članak o zahvatu i istraživanju slike u autorstvu Žane Matulić Bilač, Jelene Zagore i Zoraide Demori Staničić. Kolegici Matulić Bilač zahvalna sam na poticaju za pisanje ovoga rada. Ovom prigodom želim zahvaliti i dr. Demori Staničić na savjetima tijekom istraživanja i pomoći u pribavljanju literature. 95 RADOSLAV TOMIĆ, 2016., 103-116.

96 Sloj nije topljiv u vodi, no analize veziva i pigmenata za sada nisu provedene (zbog kontaminacije vezivom iz brojnih preslika to će biti otežano).

97 NICO VAN HOUT, 1998., 217, 225.

98 FRANCESCA CAPANNA, ANNA MARIA MARCONE, FRANCESCA ROMANA SINAGRA, 2012., 40.

99 JELENA ZAGORA, 2013.
100 Među njima su Tizian, Tintoretto, Da Vinci, Veronese, Raffaello, Perugino i Rubens. MARY PHILADELPHIA MERRIFIELD, 1849., 86.

$101 U$ opsežnom bibliografskom istraživanju (većina literature navedena je $u$ ovome radu) nisam naišla na sličan primjer. Claudio Seccaroni i dr. Nico van Hout (kustos u Koninklijk Museum voor Schone Kunsten, Antwerpen) također se nisu susreli s takvim slikama (osobna korespondencija, travanj 2017.). Van Hout se bavio istraživanjem tehnika podslikavanja; s obzirom na to da u slikarstvu venecijanske škole brzina i ekonomičnost u kombinaciji s radom na velikim formatima određuje strategiju slikanja više nego što je to slučaj kod drugih slikarskih škola. Otkriće ga previše ne iznenađuje, no smatra da je primjer izuzetno zanimljiv i da bi trebalo ispitati je li riječ o zasebnom slučaju ili nedovoljno istraženoj tradiciji. 102 MARY PHILADELPHIA MERRIFIELD, 1849., cclxxxviii. Nije jasno o kojem je Callotu riječ; grafičar Jacques Callot (oko 1592. - 1635.), koliko mi je poznato, nije izrađivao slike.

103 MAARTJE STOLS-WITLOX, 2014., 98.

104 NICO VAN HOUT, 1998., 217. Utjecaj boje preparacije na tonalitet slike i tehniku slikanja je očigledan, no manje je izvjesno jesu li slikari (uvijek) svjesno prilagođavali boju podloge temi koju su željeli prikazati. lako autori sjevernoeuropskih povijesnih traktata pokazuju da boja i sastav preparacije mogu biti povezani s temom slike, poveznice su rijetko utvrđene u europskom, posebice u talijanskom slikarstvu ili je tema nedovoljno istražena. Za sada, doista se čini da to uvelike ovisi o ukusu slikara. U sjevernoeuropskim traktatima zabilježene su preporuke za boju podloge ovisno o spolu portretirane osobe - za žene se savjetuju svjetlije podloge, kao i za pejzaže, no Nicolas Poussin, primjerice, pejzaže je slikao na tamnosmeđim preparacijama. Neki su, pak, slikari zabilježili greške u tonu preparacije koje su im se dogodile zbog pripreme većih količina smjese. Nizozemski slikar Gerard de Lairesse jedini detaljno raspravlja o boji preparacija (1707. godine). Među ostalim piše da slikari koji žele vježbati odvažan način slikanja trebaju raditi na tamnim podlogama, čiji ton mogu prevladati samo blještavim i snažnim bojama. Vrijedi i obratno. MAARTJE STOLS-WITLOX, 2014., 210-213. Južno od Alpa, još Parmigianino boju imprimature prilagođava spolu portretirane osobe, a svakako nije slučajno da je Tintorettova slika Krist pere noge učenicima naslikana na crnoj imprimaturi - tamnog je tonaliteta, osmišljena kao noćna scena. DIEGO CAUZZI, CLAUDIO SECCARONI, 2007., 103; JOYCE PLESTERS, 1968., 265. Zanimljivo, slike grupe autora za Salón de Reinos u madridskoj palači Buen Retiro izvedene su na varijantama sivih preparacija, unatoč činjenici što za mnoge slikare uključene u projekt to nije uobičajena praksa. Sve slike prikazuju scene na otvorenom, za što su pogodne svijetle podloge, no pretpostavlja se da je postojao dogovor u planiranju tog pothvata, vjerojatno prema Velázquezovim smjernicama. Velike varijacije sastava preparacija unutar opusa pojedinih slikara, kao i neočekivane sličnosti preparacija različitih autora, u nekim se slučajevima mogu objasniti specijaliziranim radionicama za prepariranje. MARÍA DOLORES GAYO, MAITE JOVER DE CELIS, 2010., 8, 17-18, 39-59.

105 DIEGO CAUZZI, CLAUDIO SECCARONI, 2007., 106. 


\section{Izvori}

Hrvatski restauratorski zavod, JELENA ZAGORA, Konzervatorskorestauratorski zahvat i istraživanje slike Gospa od Karavaja (18. stoljeće) iz šibenske katedrale sv. Jakova (stručni rad), Split, 2015. Hrvatski restauratorski zavod, JELENA ZAGORA, Izvješće o izvedenim konzervatorsko-restauratorskim radovima na oltarnoj slici Bogorodica Bezgrešna iz crkve sv. Nedjeljice na predjelu Crnica u Šibeniku, Split, 2013. Hrvatski restauratorski zavod, DOMAGOJ MUDRONJA, MIRJANA JELINČIĆ, Laboratorijsko izvješće br. 2193/1 (2012.), Zagreb, 2012.

Hrvatski restauratorski zavod, DOMAGOJ MUDRONJA, MIRJANA JELINČIĆ, Laboratorijsko izvješće br. 191/2013., Zagreb, 2013.
Hrvatski restauratorski zavod, DOMAGOJ MUDRONJA, MIRJANA JELINČIĆ, Laboratorijsko izvješće br. 197/2014., Zagreb, 2014. Hrvatski restauratorski zavod, DOMAGOJ MUDRONJA, MIRJANA JELINČIĆ, Laboratorijsko izvješće br. 55/2015., Zagreb, 2015. Hrvatski restauratorski zavod, DOMAGOJ MUDRONJA, LEA SOVIĆ, MIRJANA JELINČIĆ, Laboratorijska izvješća br. 100/2015, 110/2015, Zagreb, 2015.

Hrvatski restauratorski zavod, DOMAGOJ MUDRONJA, MIRJANA JELINČIĆ, MARGARETA KLOFUTAR, Laboratorijska izvješća br. 253/2015 i 278/2015, Zagreb, 2015.

\section{Literatura}

DOMENICO ARTIOLI, FABIO TALARICO, Indagini chimiche sul dipinto 'San Francesco riceve le stimmate', Guercino - II 'San Francesco' ritrovato, (ur.) Francesco Gonzales i Rossana Vitiello, Milano, 2006., 65-69.

FILIPPO BALDINUCCI, II Vocabolario Toscano dell'Arte del Disegno, Firenca, 1681., edizione elettronica - Scuola Normale Superiore, (ur.) Mirella Sessa i Umberto Parrini, Pisa, 2003. URL = http:// baldinucci.sns.it (6. listopada 2017.)

MARGARET BARKOVIC, MARGARET SHEEHAN, 'Portrait of an Unknown Man', c.1612, Roman School, Research Report for the Courtauld Institute of Art Research Forum's collaborative project 'Technical Analysis and Art Historical Research', 2015., URL = http:// courtauld.ac.uk/wp-content/uploads/2015/11/Roman_School Forum-Final-Edit-26-June-2.compressed.pdf (13. travnja 2017.) BARBARA H. BERRIE, Short Communication. A Note on the Imprimatura in Two of Dosso Dossi's Paintings, Journal of the American Institute for Conservation, 33/3 (1994.), 307-313.

DAVID BOMFORD, ASHOK ROY, Canaletto's 'Stonemason's Yard' and 'San Simeone Piccolo', National Gallery Technical Bulletin, 14 (1993.), 34-41.

VIŠNJA BRALIĆ, PAVAO LEROTIĆ, Restauratorski radovi na oltarnoj slici Jacopa Palme mlađeg u Svetvinčentu, Godišnjak spomenika kulture Hrvatske, 28 (2004.), 145-159.

FRANCESCA CAPANNA, ANNA MARIA MARCONE, FRANCESCA ROMANA SINAGRA (ur.), Lavori in corso in Galleria, Restauri IsCR per le opere della collezione Doria Pamphilj, katalog izložbe (Rim, Palazzo Doria Pamphilj, 16. ožujka - 17. lipnja 2012.), Rim, 2012. FRANCESCA CAPANNA, GIULIA CERVI, FRANCESCA DAL MASCHIO, MARIA ENRICA GIRALICO, FRANCESCA MANCINELLI, MIRIAM PITOCCO, II restauro del 'San Francesco riceve le stimmate', Guercino - II 'San Francesco' ritrovato, (ur.) Francesco Gonzales i Rossana Vitiello, Milano, 2006., 59-62.

DIEGO CAUZZI, ANDREA G. DE MARCHI, PIETRO MOIOLI, CLAUDIO SECCARONI, L'Allegoria del Correggio nella Galleria Doria Pamphilj, Bollettino ICR - Nuova Serie, 24-25 (2012.), 26-37.
DIEGO CAUZZI, CLAUDIO SECCARONI, Filippo da Verona e l'evoluzione di un modello, II 'Cristo morto' di Filippo da Verona pittore itinerante, (ur.) Angelo Mazza, 2007., Cesena, 91-111. DIEGO CAUZZI, PIETRO MOIOLI, CLAUDIO SECCARONI, Materiali e tecnica in alcuni dipinti del Correggio, Bollettino ICR Nuova Serie, 30 (2015.), 39-50.

CENNINO CENNINI, Knjiga o umjetnosti. Il libro dell' arte, preveli Katarina Hraste i Jurica Matijević, Zagreb, 2007.

ANGELA CERASUOLO, Literature and Artistic Practice in SixteenthCentury Italy, prevela Helen Glanville, Brill, 2017.

ANTÓNIO JOÃO CRUZ, CARLA REGO, Scientific Study of an 18th Century Portugese Painting on Canvas and their Old Restoration: Problems of Date and Authenticity, International Journal of Conservation Science, 5/4, (2014.), 479-492.

LEONARDO DA VINCI, Trattato della pittura, (ur.) Marco Tabarrini, Rim, 1890.

JILL DUNKERTON, ASHOK ROY, Uccello's, Saint George and the Dragon: Technical Evidence Re-evaluated, National Gallery Technical Bulletin, 19 (1998.), 26-30.

JILL DUNKERTON, MARIKA SPRING et al., Titian's Painting Technique to c.1540, National Gallery Technical Bulletin - Titian's Painting Technique before 1540, 34 (2013.)

JILL DUNKERTON, MARIKA SPRING, The development of painting on coloured surfaces in sixteenth-century Italy, Studies in Conservation, 43 (1998.), 120-130.

JILL DUNKERTON, SUSAN FOISTER, NICHOLAS PENNY, Dürer to Veronese: Sixteenth-Century Painting in the National Gallery, London, 1999.

ALAIN R. DUVAL, Les enduits de préparation des tableaux de Nicolas Poussin, Technè, 1 (1994.), 35-41.

ALAIN R. DUVAL, Les préparations colorées des tableaux de l'Ecole Française des dix-septième et dix-huitième siècles, Studies in Conservation, 37/4 (1992.), 239-258.

NICHOLAS EASTAUGH, VALENTINE WALSH, TRACEY CHAPLIN, RUTH SIDDAL, Pigment Compendium: A Dictionary of Historical Pigments, Oxford-Burlington, 2008. 
ELISE EFFMANN, 'View of the Molo': A Canaletto Attribution Reinstated, Studying and Conserving Paintings: Occasional Papers on the Samuel H. Kress Collection, London - New York, 2006., 189-196. MARÍA DOLORES GAYO, MAITE JOVER DE CELIS, Evolución de las preparaciones en la pintura sobre lienzo de los siglos XVI y XVII en España, Boletín del Museo del Prado, XXVIII/46 (2010.), 39-59. Prijevod na engleski jezik: The evolution of preparations for painting on canvas in sixteenth and seventeenth century Spain (Tom Skipp, Tiarna Doherty i Gabriele Finaldy), URL = https://www. museodelprado.es/en/learn/research/studies-and-restorations/ resource/the-evolution-of-preparations-for-painting-on/39cd7ac7b445-49da-9362-61dbc19c5ed8 (29. siječnja 2017.)

HELEN GLANVILLE, Varnish, Grounds, Viewing Distance, and Lighting: Some Notes on Seventeenth-Century Italian Painting Technique, Historical Painting Techniques, Materials and Studio Practice: preprints of a symposium (Leiden, 26. - 29. lipnja 1995.), (ur.) Arie Wallert, Erma Hermens i Marja Peek, Los Angeles, 1995., 12-19. KARIN GROEN, Earth Matters: The origin of the material used for the preparation of the Night Watch and many other canvases in Rembrandt's workshop after 1640, Art Matters, 3 (2005.a), 138-154.

KARIN GROEN, Grounds in Rembrandt's workshop and in paintings by his contemporaries, Paintings in the laboratory: scientific examination for art history and conservation (doktorska disertacija), Amsterdam (Instituut voor Cultuur en Geschiedenis), 2011., 318-334, URL = http://hdl.handle.net/11245/2.88981 (21. studenoga 2014.)

KARIN GROEN, In the Beginning there was Red, The Learned Eye: Regarding Art, Theory, and the Artist's Reputation: Essays for Ernst van de Wetering, (ur.) Marieke van den Doel, Natasja van Eeck, Gerbrand Korevaar, Anna Tummers i Thijs Weststeijn, Amsterdam, 2005. b, 18-27.

TOMÁŠ GRYGAR, JANKA HRADILOVÁ, DAVID HRADIL, PETR BEZDIČKA, SNEJANA BAKARDIJEVA, Analysis of earthy pigments in grounds of Baroque paintings, Analytical and Bioanalytical Chemistry, 375 (2003.), 1154-1160.

MOJMÍR HAMSÍk, The Technique of Italian Painting of the 17th and 18th Century. The System of the Ground Layers, Technologia Artis, 3 (1993.), URL = https://technologiaartis.avu.cz/a 3malbaplatno-technika.html\# (7. srpnja 2017.)

KATE HELWIG, Iron Oxide Pigments: Natural and Synthetic, Artists' Pigments. A Handbook of Their History and Characteristics, (ur.) Barbara H. Berrie, 2007., 39-109.

PHILIP HENDY, ARTHUR S. LUCAS, JOYCE PLESTERS, The ground in pictures, Museum, 21/4 (1968.), 245-265.

ERMA HERMENS, JOYCE TOWNSEND, Binding media, Conservation of Easel Paintings, (ur.) Joyce Hill Stoner i Rebecca Rushfield, Abingdon - New York, 2012., 207-289.

DAVID HRADIL et al, Change of ground layers composition of Italian 16th to 17th century paintings and its influence to the painting technique of the central Europe, CHARISMA ARCHLAB Access report, 2011., URL = http://www.charismaproject.eu/media/80186/opd_hradilnew.pdf (23. rujna 2013.)
DAVID HRADIL, JANKA HRADILOVÁ, PETR BEZDIČKA, SILVIE ŠVARCOVA, Differentiation between anonymous paintings of the 17 th and the early 18 th century by composition of clay-based grounds, Applied Clay Science, 118 (2015.), 8-20.

JANKA HRADILOVÁ, DAVID HRADIL, Gothic canvas painting: an example of technology responding to requirements of the liturgy, Kermes quaderni, VIth European Symposium on Religious Art, Restoration \& Conservation, (Firenca, 9. - 11. lipnja 2014.), (ur.) Oana Adriana Cuzman, Rachele Manganelli Del Fà, Piero Tiano, Firenca, 2014.,116-119.

SUSAN JONES, Painting in Oil in the Low Countries and Its Spread to Southern Europe, Heilbrunn Timeline of Art History, listopad 2000., New York: The Metropolitan Museum of Art, URL = http://www.metmuseum.org/toah/hd/optg/hd_optg.htm (7. srpnja 2017.)

JO KIRBY, The Painter's Trade in the Seventeenth Century: Theory and Practice, National Gallery Technical Bulletin, 20 (1999.), 5-49. ANDREA KIRSH, RUSTIN S. LEVENSON, Seeing Through Paintings: Physical Examination in Art Historical Studies, New Haven - London, 2000.

SHARON LA BODA, International Dictionary of Historic Places: Southern Europe, Chicago - London, 1994.

CARLO LALLI, Preliminarne analize cjeline „Četiri evanđelista“ iz crkava Gospe od Karmena i sv. Vlaha u Dubrovniku, Četiri evanđelja u opusu Mattije Prettija. Rezultati savjetovanja održanog u Dubrovniku (Dubrovnik, 16. i 17. listopada 2008.), (ur.) Mara Kolić Pustić, Dubrovnik, 2009., 24-27.

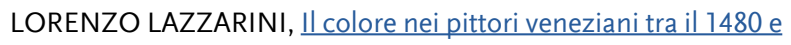
il 1580, Bollettino d'Arte, Studi veneziani, Supplemento 5 (1983.), 135-144.

PAVAO LEROTIĆ, TEA ZUBIN FERRI, Multidisciplinarna istraživanja i valorizacija kopija na primieru .Otmice Europe" iz Rijeke, Portal, godišnjak Hrvatskog restauratorskog zavoda, 4 (2013.), 153-170. PAVAO LEROTIĆ, VIŠNJA BRALIĆ, Slikarska tehnika i materijali, Restauriranje Tizianove slike iz crkve sv. Dominika u Dubrovniku, (ur.) Višnja Bralić, Zagreb - Dubrovnik, 2008., 77-90.

STEFANO MARCONI, Preparazione e imprimiture dei dipinti su tavola e tela: materiali, metodi e storia, Preparazione e finiture delle opere pittoriche - materiali e metodi, (ur.) Corrado Maltese, Mursia, 1993., 10-38.

ELISABETH MARTIN, Grounds on canvas 1600 - 1640 in various European artistic centres, Preparation for Painting. The Artist's Choice and its Consequences, (ur.) Joyce H. Townsend, Tiarna Doherty, Gunnar Heydenreich i Jacqueline Ridge, London, 2008., 59-67. ANN MASSING, From Books of Secrets to Encyclopedias: Painting Techniques in France between 1600 and 1800, Historical Painting Techniques, Materials, and Studio Practice: preprints of a symposium (Leiden, 26. - 29. lipnja 1995.), (ur.) Arie Wallert, Erma Hermens i Marja Peek, Los Angeles, 1995., 20-29.

MARY PHILADELPHIA MERRIFIELD, Original Treatises, Dating from the XIIth to the XVIIIth Centuries, on the Arts of Painting, London, 1849.

ELMA O'DONOGHUE, RAFAEL ROMERO, JORIS DIK, French Eighteenth-Century Painting Tedchniques, Painting Techniques: 
History, materials, studio practice: Contributions to the Dublin Congress (Dublin, 7. - 11. rujna 1998.), (ur.) Ashok Roy i Perry Smith, London, 1998., 185-189.

VIOLA PEMBERTON-PIGOTT, The Development of Canaletto's Painting Technique, Canaletto, (ur.) Katharine Baetjer i J. G. Links, New York, 1989., 53-64.

NICHOLAS PENNY, MARIKA SPRING, Veronese's Paintings in the National Gallery Technique and Materials: Part I, National Gallery Technical Bulletin, 16 (1995.), 32-55.

DAVID ROSAND, The Crisis of the Venetian Renaissance Tradition, L'arte, 11/12 (1970.), 5-53.

ANDREA ROTHE, DAWSON W. CARR, The Technique of Dosso Dossi: Poetry with Paint, Dosso Dossi: Court Painter in Renaissance Ferrara, (ur.) Andrea Bayer, New York, 1998., 55-64.

ASHOK ROY, Rubens's 'Peace and War', National Gallery Technical Bulletin, 20 (1999.a), 89-95.

ASHOK ROY, The National Gallery Van Dycks: Technique and Development, National Gallery Technical Bulletin, 20 (1999.b), 50-83. ROXANE SPERBER, JENS STENGER, Canaletto's Colour: the inspiration and implications of changing grounds, pigments and paint application in the artist's English period, British Art Studies, 2 (2016.), URL = https://doi.org/10.17658/issn.2058-5462/ issue-02/rsperber-jstenger (7. srpnja 2017.)

MAARTJE STOLS-WITLOX, Grounds, 1400 - 1900, u: Conservation of Easel Paintings, (ur.) Joyce Hill Stoner i Rebecca Rushfield, Abingdon - New York, 2012., 161-189.

MAARTJE STOLS-WITLOX, Historical recipes for preparatory layers for oil paintings in manuals, manuscripts and handbooks in North
West Europe, 1550-1900: analysis and reconstructions, 2014., URL = http://hdl.handle.net/11245/1.430263 (1. rujna 2017.) SICO SUMMERECKER, Podloge štafelajske slike, Beograd, 1973. RADOSLAV TOMIĆ, Bilješke o slikama u Šibeniku, Pirovcu, Kaštel Štafiliću, Poljicima, Skradinu, Biogradu i Zadru (Angelo Mancini, Mate Otoni, Giuseppe Marcatti, Franjo Gianacchi, Pietro Tantini), Radovi Instituta za povijest umjetnosti, 40 (2016.), 103-116. ERNST VAN DE WETERING, Rembrandt: The Painter at Work: Revised Edition, Berkeley - Los Angeles, 2009. [Amsterdam, 1997.] NICO VAN HOUT, Meaning and Development of the Ground Layer in Seventeenth Century Painting, Looking through Paintings: The Study of Painting Techniques and Materials in Support of Art Historical Research, (ur.) Erma Hermens, Annemiek Ouwerkerk i Nicola Costaras, London, 1998., 199-225.

GIORGIO VASARI, Le vite de' piu eccellenti pittori scultori e architettori, Firenca, 1568, vol. 1-2. URL = https://archive.org (6. listopada 2017.)

ZAHIRA VELIZ, Francisco Pacheco's comments on painting in oil, Studies in Conservation, $27 / 2$ (1982.), 49-57.

JELENA ZAGORA, Prugasta platna za izradu madraca kao nosioci slika - povijesni pregled uz analizu nekoliko primjera iz Dalmacije, Portal, godišnjak Hrvatskog restauratorskog zavoda, 7 (2016.), 251-274.

JELENA ZAGORA, SEM-EDX Pigment Analysis and Multi-Analytical Study of the Ground and Paint layers of Francesco Fedrigazzi's painting from Kostanje, CeROArt (elektronički časopis), 3 (2013.), objavljeno 20. svibnja 2013., URL = http://ceroart.revues.org/3248 (13. travnja 2017.)

\section{Summary}

\section{Jelena Zagora}

HISTORICAL DEVELOPMENT OF COLOURED GROUNDS IN ITALIAN PAINTING FROM THE $15^{\text {TH }}$ TO THE MID- $18^{\text {TH }}$ CENTURY - PRESENT INSIGHTS AND OPEN QUESTIONS

Aiming to set the guidelines for future research on preparations of Dalmatian paintings of Italian origin, this paper presents an overview of the historical development of coloured painting grounds in Italy from the $15^{\text {th }}$ to the mid- $18^{\text {th }}$ century. The development of coloured painting grounds in the history of European painting is examined through art-historical, stylistic and technological parameters, such as the transition from tempera to oil painting and the introduction of canvas as the main painting ground in the $16^{\text {th }}$ century. Preparations from gypsum (gesso) and chalk and glue, discovered in the earliest surviving examples of oil paintings on canvas, were a follow-up to the tradition of preparation of paintings on wood. From non-pigmented isolation layers pigmented imprimaturas were developed; however, the earliest known coloured grounds in Italian painting were preparations from gesso, with an addition of red pigment, in the works of Venetian paint- ers of the second half of the $15^{\text {th }}$ century. Imprimaturas of bright or varying colours, as well as local imprimaturas, appeared in the late $15^{\text {th }}$ century in the plain of the River Po. In the following century, single-layer gesso preparations (popular in Venice) were often used for the preparation of canvases, but gesso with imprimatura was the most common primer. In the early $16^{\text {th }}$ century, Correggio, Filippo da Verona, Titian and painters of the Brescia School introduced coloured preparations for canvases based on earth pigments. In the $17^{\text {th }}$ century, throughout Italy, brown preparations of various compositions were the most common ones. Red preparations of the $18^{\text {th }}$ century have not been sufficiently researched: despite claims of their having appeared in Bologna in the late $16^{\text {th }}$ century, it was at this time that they also appeared in northern Europe, and have traditionally been linked to Venetian painting of the $18^{\text {th }}$ century. How and when they originated, and what 
varieties there are to their composition, remains unclear. Double preparations appeared in the $16^{\text {th }}$ century in the north of the Low Countries and in Flanders, from where they spread across Europe in the $17^{\text {th }}$ and $18^{\text {th }}$ centuries. There are records of them in Italy as early as the beginning of the $17^{\text {th }}$ century and in the $18^{\text {th }}$, but these are little researched; there are records of them in Dalmatia as well. The question of binders for coloured preparations based on earth pigments in the $17^{\text {th }}$ and $18^{\text {th }}$ centuries, especially on paintings by Italian authors, calls for more attention. References in the literature mention mostly oil; however, judging from the experiences of Italian and Dalmatian restorers, what we are often dealing with are hydrophilic binders. An unusual example of an underpainting used as a preparation, in fact a coloured ground of varying tone (ochre to brown), was found in Dalmatia on a painting by Venetian master Angelo Mancini from 1609. According to the author's research so far, no similar example could be confirmed in oil painting on canvas; this matter, however, calls for a more comprehensive study.
There is no precise division of various types of preparation from different periods or provenances, not even within a single author's oeuvre: many painters were changing the colour of the preparation depending on the subject matter, mood or technique of painting. We can also observe a coexistence and survival of old methods of preparation, i.e. a gradual, heterogeneous adoption of new trends. It is perhaps due to the deposits of various earth pigments in the plain between the rivers Po and Adige that brown and red preparations first appeared and developed in the north of Italy, in this brick-built region. What is certain is that our insights will change and be supplemented with new research on painting preparations and earth pigments.

KEYWORDS: pigmented gesso, imprimatura, coloured preparations, double preparations, underpainting, painting on wood, oil painting on canvas 